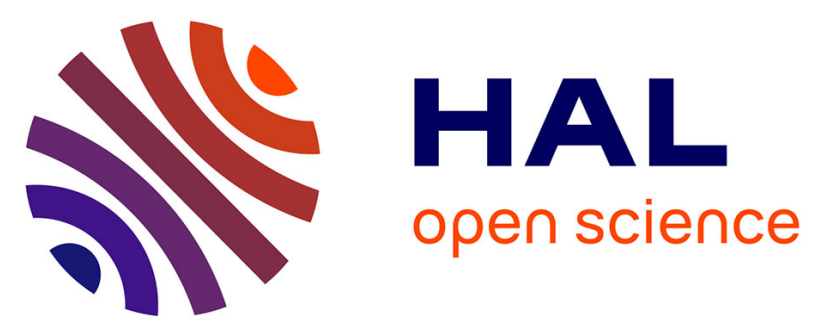

\title{
Limited impact of ocean acidification on phytoplankton community structure and carbon export in an oligotrophic environment: Results from two short-term mesocosm studies in the Mediterranean Sea
}

Frédéric Gazeau, A. Sallon, P. Pitta, A. Tsiola, L. Maugendre, M. Giani, M. Celussi, M.L. Pedrotti, S. Marro, Cecile Guieu

\section{To cite this version:}

Frédéric Gazeau, A. Sallon, P. Pitta, A. Tsiola, L. Maugendre, et al.. Limited impact of ocean acidification on phytoplankton community structure and carbon export in an oligotrophic environment: Results from two short-term mesocosm studies in the Mediterranean Sea. Estuarine, Coastal and Shelf Science, 2017, 186 (A), pp.72-88. 10.1016/j.ecss.2016.11.016 . hal-01401698

\section{HAL Id: hal-01401698 \\ https://hal.sorbonne-universite.fr/hal-01401698}

Submitted on 23 Nov 2016

HAL is a multi-disciplinary open access archive for the deposit and dissemination of scientific research documents, whether they are published or not. The documents may come from teaching and research institutions in France or abroad, or from public or private research centers.
L'archive ouverte pluridisciplinaire HAL, est destinée au dépôt et à la diffusion de documents scientifiques de niveau recherche, publiés ou non, émanant des établissements d'enseignement et de recherche français ou étrangers, des laboratoires publics ou privés. 
1 Limited impact of ocean acidification on phytoplankton

2 community structure and carbon export in an oligotrophic

3 environment: results from two short-term mesocosm studies in

4 the Mediterranean Sea

Gazeau, F. ${ }^{1,2 *}$, Sallon, A. ${ }^{1,2}$, Pitta, P. ${ }^{3}$, Tsiola, A. ${ }^{3,4}$, Maugendre, L. ${ }^{1,2}$, Giani M. ${ }^{5}$, Celussi M. ${ }^{5}$, Pedrotti, M. L. ${ }^{1,2}$, Marro, S. ${ }^{1,2}$ and Guieu, C. ${ }^{1,2}$

[1] Sorbonne Universités, UPMC Univ Paris 06, UMR 7093, LOV, Observatoire océanologique, F-06230, Villefranche/mer, France

[2] CNRS, UMR 7093, LOV, Observatoire océanologique, F-06230, Villefranche/mer, France

[3] Hellenic Centre for Marine Research, Institute of Oceanography, PO Box 2214, 71003 Heraklion, Crete, Greece

[4] University of Crete, Department of Biology, University Campus, 70013, Heraklion, Crete, Greece

[5] Oceanography Division, OGS (Instituto Nazionale di Oceanografia e di Geofisica Sperimentale), v. A. Piccard 54, I-34151 Trieste, Italy

* Correspondence:

Dr. Frédéric Gazeau

Laboratoire d'Océanographie de Villefranche

CNRS-UPMC, UMR 7093

06230 Villefranche-sur-mer

FRANCE

f.gazeau@obs-vlfr.fr

Highlights:

- Two large mesocosm experiments carried out in the Northwestern Mediterranean Sea

- Experiments conducted in the summer oligotrophic $v s$. winter mesotrophic periods

- Production limited by nutrient availability and community dominated by small species

- Organic matter export was not impacted by $\mathrm{CO}_{2}$-enrichment

- In areas where nutrient availability exerts a strong pressure on phytoplankton growth, $\mathrm{CO}_{2}$ addition will likely have very limited effects on phytoplankton diversity

Keywords:

Ocean acidification; Pelagic mesocosms; Mediterranean Sea; Oligotrophic area;

Phytoplankton community 
44 Abstract

Modifications in the strength of the biological pump as a consequence of ocean acidification, whether positive or negative, have the potential to impact atmospheric $\mathrm{CO}_{2}$ and therefore climate. So far, most plankton community perturbation studies have been performed in nutrient-rich areas although there are some indications that $\mathrm{CO}_{2}$-dependent growth could differ in nutrient-replete vs. -limited regions and with different community compositions. Two in situ mesocosm experiments were performed in the NW Mediterranean Sea during two seasons with contrasted environmental conditions: summer oligotrophic stratified waters in the Bay of Calvi vs. winter mesotrophic well-mixed waters in the Bay of Villefranche. Nine mesocosms were deployed for 20 and $12 \mathrm{~d}$, respectively, and subjected to seven $\mathrm{CO}_{2}$ levels (3 controls, 6 elevated levels). Both phytoplankton assemblages were dominated by pico- and nano-phytoplankton cells. Although haptophyceae and dinoflagellates benefited from shortterm $\mathrm{CO}_{2}$ enrichment in summer, their response remained small with no consequences on organic matter export due to strong environmental constraints (nutrient availability). In winter, most of the plankton growth and associated nutrient consumption occurred during the 4-day acidification period (before the experimental phase). During the remaining experimental period, characterized by low nutrient availability, plankton growth was minimal and no clear $\mathrm{CO}_{2}$-dependency was found for any of the tested parameters. While there is a strong confidence on the absence of significant effect of short-term $\mathrm{CO}_{2}$ addition under oligotrophic conditions, more investigations are needed to assess the response of plankton communities in winter when vertical mixing and weather conditions are major factors controlling plankton dynamics. 


\section{Introduction}

During the last 150 years, human activities, through the combustion of fossil fuels (oil, gas and coal), have led to a dramatic release of carbon dioxide $\left(\mathrm{CO}_{2}\right)$ to the Earth's atmosphere. The accumulation of $\mathrm{CO}_{2}$ impacts the radiative forcing, thereby warming the atmosphere and the ocean. The ocean acts as a climate integrator that absorbed $93 \%$ of Earth's additional heat since the 1970s, offsetting much atmospheric warming but increasing ocean temperature and sea level and captured $28 \%$ of anthropogenic $\mathrm{CO}_{2}$ emissions since 1750 (Gattuso et al., 2015). Although providing a valuable human service by moderating the rate and severity of global warming, the consequence of this oceanic $\mathrm{CO}_{2}$ pump is the ongoing increase in ocean acidity (i.e. decrease in $\mathrm{pH}$ ). Surface ocean $\mathrm{pH}$ has already decreased by 0.1 units since the beginning of the industrial era (i.e. increased acidity of $30 \%$; Ciais et al., 2013). According to recent projections and depending on the emission scenario considered, an additional decrease ranging between 0.06 and 0.32 units is expected by 2100 (Ciais et al., 2013).

The decrease in seawater $\mathrm{pH}$ leads to a decrease in the concentration of carbonate ions $\left(\mathrm{CO}_{3}{ }^{2-}\right)$, one of the building blocks of calcium carbonate $\left(\mathrm{CaCO}_{3}\right)$, and alters the ability of many calcifying organisms to precipitate $\mathrm{CaCO}_{3}$ (e.g. Kroeker et al., 2013). In addition, a decrease in seawater $\mathrm{pH}$ leads to an increase in dissolved $\mathrm{CO}_{2}$ and bicarbonate $\left(\mathrm{HCO}_{3}{ }^{-}\right)$ concentrations. Carbon fixation by marine photosynthetic organisms represents about $50 \%$ of global Earth primary production (Field et al., 1998), and the export of part of the produced organic matter from the sunlit surface layer to the deep-ocean (i.e. the biological or soft-tissue pump) is responsible for $\sim 70 \%$ of surface to deep-ocean dissolved inorganic carbon $\left(C_{\mathrm{T}}\right)$ gradients (Sarmiento and Gruber, 2006). Therefore, modifications in the strength of this 
biotically mediated carbon pump, whether positive or negative, have the potential to impact atmospheric $\mathrm{CO}_{2}$ and therefore climate (Riebesell et al., 2007).

$\mathrm{CO}_{2}$ rather than the much more abundant $\mathrm{HCO}_{3}{ }^{-}$is the substrate used in the carbon fixation step of photosynthesis and RubisCO, the enzyme catalyzing this reaction, has a low affinity for $\mathrm{CO}_{2}$ (Badger et al., 1998; Giordano et al., 2005). As such, this enzyme is theoretically not saturated under current ambient $\mathrm{CO}_{2}$ levels (Badger et al., 1998). However, nearly all marine species have developed various mechanisms (carbon concentration mechanisms or $\mathrm{CCMs}$ ) to compensate for this low $\mathrm{CO}_{2}$ availability through the energydemanding use of carbonic anhydrase enzymes or active $\mathrm{CO}_{2}$ and/or bicarbonate transports through membranes (Raven et al., 2014). There is evidence that both the RubisCO affinity for $\mathrm{CO}_{2}$ as well as the efficiency of these CCMs differ widely among taxa, species or even strains (Tortell, 2000; Young et al., 2016), complicating the prediction of whether a cell's carbon fixation rate will respond directly to ambient changes in $\mathrm{CO}_{2}$ availability through increased $\mathrm{CO}_{2}$ diffusion and/or less energy expenditure needed to operate CCMs (Mangan et al., 2016; Raven and Beardall, 2014). Finally, although downregulation of CCMs at elevated $\mathrm{CO}_{2}$ has been observed, the significance of this downregulation to overall cell physiology and growth is not currently well constrained due to the presence of other limiting factors in the oceans such as macro- or micro-nutrients and light (Hennon et al., 2015; Young and Morel, 2015). All of this can partly explain the very diverse findings that have been documented on the effect of increased ambient $\mathrm{CO}_{2}$ availability on photosynthesis and growth of marine phytoplankton (Dutkiewicz et al., 2015).

Apart from the above-mentioned variability in RubisCO affinity for $\mathrm{CO}_{2}$ and $\mathrm{CCMs}$ efficiency, a significant part of the observed discrepancies among available perturbation studies could be explained by differences in experimental setups and environmental conditions such as temperature, light conditions and nutrient availability. Phytoplankton 
114 growth obviously does not only depend on carbon availability but on a combination of

115 physico-chemico-biological drivers such as macro- and micro-nutrient availability,

116 temperature, light, competition and grazing. It is therefore very likely that the response of

117 phytoplankton will differ depending on these environmental conditions (Verspagen et al.,

118 2014). Furthermore, as this is the amount of organic matter that can escapes the sunlit layer

119 that determines the capacity of the surface ocean to pump atmospheric $\mathrm{CO}_{2}$, there is a great

120 need to evaluate the impact of $\mathrm{CO}_{2}$, not only on phytoplankton growth but on the export of

121 this organic matter to deeper layers. The build-up of organic matter and its potential export

122 strongly depends on phytoplankton community composition (Eggers et al., 2014). Indeed,

123 large cells (e.g. diatoms) account for a large proportion of export production and ultimate

124 burial in sediments (Finkel et al., 2005). In contrast, small cells (nano- and pico-plankton) are

125 particularly important in regions with limited nutrient availability with a close coupling

126 between production and grazing through the microbial loop and a with low export capacity

127 (Riebesell and Tortell, 2011). As already mentioned, differing responses to increased $\mathrm{CO}_{2}$

128 availability between different functional groups, size classes and species (Dutkiewicz et al.,

129 2015) have the potential to significantly alter community structure and functioning. In that

130 sense, studies focused on plankton assemblages rather than on isolated single species and

131 under very contrasted environmental conditions are very informative (Tarling et al., 2016).

132 During the last decade, there has been a noticeable increase in the number of

133 experimental assessments of the sensitivity of plankton community compositions to the on-

134 going increase in $\mathrm{CO}_{2}$. These experiments were conducted in various areas of the world ocean

135 using different approaches, from small bottle incubations to large mesocosm deployments,

136 and over different time scales (few days to few weeks). Several of these experiments

137 highlighted significant modifications of community compositions under elevated $\mathrm{CO}_{2}$ levels.

138 For instance, $\mathrm{CO}_{2}$ enrichment has been shown to stimulate growth of large species such as 
139 diatoms (e.g. Domingues et al., 2014; Feng et al., 2009; Reul et al., 2014; Tortell et al., 2002;

140 Tortell et al., 2008; Wu et al., 2014). Several experiments suggested stimulating effects on

141 small species (pico-phytoplankton; e.g. Newbold et al., 2012; Paulino et al., 2008; Schulz et

142 al., 2013). In contrast, Richier et al. (2014) reported significant decrease in the growth of

143 small phytoplankton species $(<10 \mu \mathrm{m})$ suggesting that small species are less adapted to

144 changes in their local $\mathrm{pH}$ while larger cells must face larger $\mathrm{pH}$ variations at short time scales

145 (Flynn et al., 2012). Other studies showed differential responses between species from the

146 same taxa (e.g. Endo et al., 2016; Feng et al., 2010; Kim et al., 2006; Meakin and Wyman,

147 2011) and finally among different phylotypes and phenotypes of the same species (e.g.

148 Brading et al., 2011; Rickaby et al., 2016).

149 Whether or not these modifications of community structure (e.g. increase or decrease

150 in cell size) can modify the amount of organic matter sinking to deeper layers can be

151 evaluated through the use of mesocosms. They are defined as experimental enclosures from 1

152 thousand to several thousands of litres that allow the maintenance of natural communities

153 under close-to-natural conditions and the collection of sinking organic matter (Riebesell et al.,

154 2008; Riebesell et al., 2013a). In recent years, plankton community studies performed using

155 such experimental systems have led to very contrasted outcomes in terms of community

156 composition and carbon export responses to $\mathrm{CO}_{2}$ enrichment (see Table 1). Most of these

157 experiments have been performed in nutrient-rich areas (or following artificial nutrient

158 enrichment) dominated by large species and experiments conducted in areas limited by

159 nitrate, phosphate and/or iron are currently lacking (Paul et al., 2015a). These areas represent

160 a very large surface area of the ocean and are projected to expand in the coming decades

161 because of enhanced thermal stratification and nutrient depletion (Irwin and Oliver, 2009;

162 Polovina et al., 2008). As already mentioned, they are usually dominated by small cells

163 adapted to low-nutrient conditions and have low export capacities. Recently, and in contrast 
164 to theoretical considerations (Verspagen et al., 2014), two mesocosm experiments suggested

165 that communities exposed to low nutrient concentrations may be more responsive to $\mathrm{CO}_{2}$

166 enrichment than previously thought (Bach et al., 2016; Paul et al., 2015a). This was

167 confirmed recently by Sala et al. (2016) based on indoor experiments in a coastal site of the

168 Western Mediterranean Sea. During these experiments, effects of ocean acidification, i.e.

169 positive effect on pico- and nano-phytoplankton, were more important when nutrient

170 concentrations were low. However, it must be stressed that nutrient and chlorophyll levels

171 observed during these experiments were representative of an urbanized coastal area and much

172 higher than levels usually observed in the vast majority of the Mediterranean Sea.

173 The Mediterranean Sea is generally considered as oligotrophic but actually exhibits a

174 gradient from mesotrophic-oligotrophic in the western basin to ultra-oligotrophic in the

175 eastern basin (The Mermex group, 2011). These features are induced by the different

176 localizations of the physical (the winter mixed layer) and nutrient (the nutricline) vertical

177 interfaces, which are both determined by the large-scale circulation pattern (The Mermex

178 group, 2011). Based on satellite-derived estimates, chlorophyll $a$ concentrations exhibit low

179 values (less than $0.2 \mu \mathrm{g} \mathrm{L}^{-1}$ ) over most of the Mediterranean Sea, except for the Liguro-

180 Provençal region where large blooms can be observed in late winter-early spring (D'Ortenzio

181 and d'Alcala, 2009). Overall, phytoplankton communities are dominated by pico-

182 phytoplankton (Siokou-Frangou et al., 2010). However, because of its very diversified

183 (spatially and temporally) physical structure, localized higher nutrient availability can drive

184 more intense biological activities and transient dominance of larger species such as diatoms

185 and dinoflagellates (Bustillos-Guzmán et al., 1995). Diatoms are more abundant during the

186 transition between mixed and stratified conditions (Claustre et al., 1994). These features make

187 the Mediterranean Sea a perfect natural laboratory to study the effects of nutrient availability

188 and community composition on the response of plankton community to $\mathrm{CO}_{2}$ enrichment. 
In the frame of the European project 'Mediterranean Sea Acidification under changing

190 climate' (MedSeA; http://medsea-project.eu), for the first time, two short-term in situ

191 mesocosm experiments were performed in the Northwestern Mediterranean Sea during two

192 seasons with contrasted environmental conditions (i.e. summer oligotrophic stratified waters

193 vs. winter mesotrophic well-mixed waters) and different phytoplankton community

194 compositions (i.e. higher proportion of diatoms and lower proportion of pico-phytoplankton

195 and cyanophyceae in winter compared to summer). In this paper, we report on the response of

196 the phytoplankton community composition as well as of particulate organic matter dynamics

197 and export to $\mathrm{CO}_{2}$-enrichment.

\section{2. Material and Methods}

\subsection{Study sites and experimental set-up}

Two mesocosm experiments were conducted in the Northwestern Mediterranean Sea:

201 the first one, in the Bay of Calvi (Corsica, France) in summer (June-July 2012), and the second one in the Bay of Villefranche (France) in winter (February-March 2013). The experimental set-up and mesocosm characteristics are fully described in Gazeau et al. (in press, this issue). Briefly, for each experiment, nine mesocosms of ca. $50 \mathrm{~m}^{3}$ (2.3 $\mathrm{m}$ in diameter and 12 m deep) were deployed for 20 and 12 days in the Bay of Calvi and the Bay of Villefranche, respectively. Once the bottom of the mesocosms was closed, $\mathrm{CO}_{2}$ saturated seawater was added to obtain a $p \mathrm{CO}_{2}$ gradient across mesocosms ranging from ambient levels to $1,250 \mu$ atm, with three control mesocosms $(\mathrm{C} 1, \mathrm{C} 2$ and $\mathrm{C} 3)$ and six mesocosms with

209 increasing $p \mathrm{CO}_{2}$ (P1 to P6). In the Bay of Calvi, the six targeted elevated $p \mathrm{CO}_{2}$ levels were 210 P1: 550, P2: 650, P3: 750, P4: 850, P5: 1000 and P6: $1250 \mu \mathrm{atm}$. In the Bay of Villefranche, 211 the levels were P1: 450, P2: 550, P3: 750, P4: 850, P5: 1000 and P6: $1250 \mu$ atm. Mesocosms 212 were grouped in clusters of 3 with each cluster containing a control, a medium and a high 
$213 \quad p \mathrm{CO}_{2}$ level (cluster 1: C1, P1, P4; cluster 2: C2, P2, P5 and cluster 3: C3, P3, P6).

214 Acidification of the mesocosms was performed over four days by homogenous addition of

215 various volumes of $\mathrm{CO}_{2}$-saturated seawater. Once targeted $p \mathrm{CO}_{2}$ levels were reached, the

216 experiment started (day $0=24$ June 2012 and 22 February 2013 for the Bay of Calvi and the

217 Bay of Villefranche, respectively). No further $\mathrm{CO}_{2}$ additions were performed during the

218 experiments and $p \mathrm{CO}_{2}$ levels evolved in mesocosms as a consequence of air-sea fluxes,

219 temperature changes and plankton net community production. Weather permitting,

220 conductivity-temperature-depth (CTD) casts were performed on a daily basis in each

221 mesocosm and in the external environment. Surface irradiance (photosynthetically active

222 radiation; PAR) was measured continuously during the two experiments using a LI-COR LI-

223 192SA 2-Pi sensor connected to a LI-1400 data logger (Gazeau et al., in press, this issue).

224 Vertical attenuation coefficients were estimated daily in each mesocosms, based on PAR

225 profiles (0-12 m) performed using a QSP-2200 4-Pi sensor (Biospherical Instruments Inc.)

226 mounted on the CTD. Mean daily photon doses were calculated using surface PAR and

227 estimated attenuation coefficients. In the Bay of Calvi, wind speed and direction were

228 recorded with a THIES@ anemometer deployed, by the University of Liège (Belgium), on top

229 of one of buildings of the at $11.8 \mathrm{~m}$ height at a distance of about $400 \mathrm{~m}$ from the mesocosms.

230 For the experiment in the Bay of Villefranche, wind speed data (daily averages) were

231 obtained from the Météo France station at the Nice-Côte d'Azur International Airport

$232 \quad\left(43^{\circ} 39^{\prime} 55^{\prime \prime} \mathrm{N}, 7^{\circ} 12^{\prime} 48^{\prime \prime} \mathrm{E}\right)$.

\section{2.2. Sampling and analytical methods}

234 Depth-integrated (0-10 m) samplings from the mesocosms and the external

235 environment (referred thereafter to as OUT) were performed daily at 8:30 (local time) during

236 both experiments. All three clusters were simultaneously sampled from a plastic platform by

237 three teams of two scientists, each using an integrating water sampler (IWS; HYDRO- 
BIOS(C). The IWS units were hanged on a Kevlar cordage and downcasts were performed manually at a regular speed of $10 \mathrm{~cm} \mathrm{~s}^{-1}$ after rinsing it outside the mesocosms. directly frozen in liquid nitrogen and stored at $-80{ }^{\circ} \mathrm{C}$ pending analysis at the Laboratoire d'Océanographie de Villefranche (France). Filters were extracted at $-20{ }^{\circ} \mathrm{C}$ in $3 \mathrm{~mL}$ methanol (100\%), disrupted by sonication and clarified one hour later by vacuum filtration through GF/F filters. The extracts were rapidly analyzed (within $24 \mathrm{~h}$ ) by high performance liquid chromatography (HPLC) with a complete Agilent Technologies system. The pigments were separated and quantified as described in Ras et al. (2008). Synechococcus, Prochlorococcus, autotrophic pico-eukaryotes and nano-eukaryotes abundances were determined by flow cytometry analysis from samples taken every 2 days at 4:00 and 5:00 in the Bay of Calvi and the Bay of Villefranche, respectively (local times). Seawater samples $(2 \mathrm{~mL})$ from each mesocosm were immediately fixed with $0.2 \mu \mathrm{m}$ prefiltered $25 \%$ glutaraldehyde $(0.5 \%$ final concentration $)$, kept at $4{ }^{\circ} \mathrm{C}$ for approximately 30 min, then flash frozen in liquid nitrogen and finally stored at $-80{ }^{\circ} \mathrm{C}$ until further processing (Troussellier et al., 1995; Vaulot et al., 1989). Single cell analysis was processed with a maximum flow rate of $65 \mu \mathrm{L} \mathrm{min}{ }^{-1}$ through a Becton Dickinson, FACSCalibur flow cytometer, equipped with an air-cooled Argon laser emitting at $488 \mathrm{~nm}$ and analyzed with the accurately defined by systematically adding to the samples fluorescent latex beads suspensions of $1 \mu \mathrm{m}$ (Polysciences Inc., Europe) at a concentration of $2.5 \times 10^{5}$ beads $\mathrm{mL}^{-1}$.

260 The abundance of autotrophic prokaryotes and pico- and nano eukaryotes was assessed from 261 unstained samples following the method described by Marie et al. (1999). In the Bay of 262 Villefranche, four groups were determined based on the optical parameters characterizing 
each cell. Synechococcus $(<1.5 \mu \mathrm{m})$ cells were detected by their signature in a plot of orange

264 fluorescence (FL2, 565-592 nm wavelength ranges) vs. red fluorescence (FL3, > $620 \mathrm{~nm}$ ).

Prochlorococcus, autotrophic pico-eukaryotes $(<2 \mu \mathrm{m})$ and nano-eukaryotes $(2-10 \mu \mathrm{m})$

were detected in a plot of SSC vs. red fluorescence (FL3, > $620 \mathrm{~nm}$ ). In the Bay of Calvi, only abundances of Synechococcus spp. and autotrophic pico-eukaryotes were assessed.

For particulate element concentrations, sampled seawater $(0.75$ - 2 L) was filtered through pre-combusted glass-fiber filters. Particulate organic carbon (POC) and nitrogen (PON) were determined at the Istituto Nazionale di Oceanografia e di Geofisica Sperimentale (Italy) using a CHNO-S elemental analyzer (Costech ECS4010) after acidification with $1 \mathrm{~N}$ $\mathrm{HCl}$ and high-temperature combustion.

Collection of sediment traps was performed by a diver on a daily basis in the Bay of Calvi and less regularly as a consequence of bad weather conditions in the Bay of Villefranche (see Gazeau et al., in press, this issue). On each occasion and for each mesocosm, divers followed the same procedure: (1) hitting the cone of the mesocosms in case some sinking material was retained on the walls, (2) waiting for 15 minutes, (3) closing the collector, (4) collecting the $250 \mathrm{~mL}$ flask screwed to the trap system, (5) immediately replacing the sampled flask by a new empty one and (6) opening the collector again. All mesocosms were sampled within 30 min. Back in the laboratory, samples were immediately preserved in a pH buffered formalin solution (5\%). Swimmers (i.e. opportunistic copepods and other zooplankton species that swim into the traps; Lee et al., 1988) larger than $1 \mathrm{~mm}$ were removed (and discarded) and the remaining material was rinsed, centrifuged, freezedried and grinded. In the Bay of Calvi, as a consequence of low amounts of material especially at the end of the experiment, daily sediment traps samples were pooled as follows: days 5-7, 8-10, 11-14 and 15-19. Total particulate matter was weighed for flux determination and subsamples were used for POC and PON measurements performed on elemental 
analyzers after acidification with $1 \mathrm{~N} \mathrm{HCl}$. Samples from the experiment in the Bay of Calvi

were analyzed at NIOZ-Yerseke (The Netherlands) on a Thermo Electron Flash 1112.

Samples from the experiment in the Bay of Villefranche were analyzed at the Laboratoire

d'Océanographie de Villefranche (LOV, France) on a Elementar Vario Pyrocube.

\section{2}

\subsection{Data analysis and statistics}

The contribution of each phytoplankton group to total phytoplankton biomass (chlorophyll $a$ ) was estimated by using the CHEMTAX program with input ratios from Rodriguez et al. (2006) and Not et al. (2007). These pigment ratios established for open ocean plankton communities were modified from the original values by comparing microscopic and flow cytometry counts to HPLC analyses from samples collected in the NW Iberian coast, an area dominated by pico- and nano-eukaryotes, as observed in our study.

All data collected during the two experiments are freely available on Pangaea, Bay of Calvi: http://doi.pangaea.de/10.1594/PANGAEA.810331 and Bay of Villefranche: http://doi.pangaea.de/10.1594/PANGAEA.835117.

For these two experiments, we chose to follow a $\mathrm{CO}_{2}$ gradient approach rather than to replicate certain levels (ANOVA approach). As already done in several similar perturbation experiments (Paul et al., 2015a; Riebesell et al., 2013b), stepwise multiple linear regression analyses were performed to establish relationships between environmental/experimental conditions including $p \mathrm{CO}_{2}$ and (1) POC and PON fluxes to the sediment traps as well as their ratios, (2) water column POC and PON concentrations and their ratios as well as (3) chlorophyll $a$-equivalent biomass or abundances of the different identified groups. Besides $p \mathrm{CO}_{2}$, other environmental conditions that have been considered were temperature, salinity, daily photon doses, daily averaged wind speeds and nutrient concentrations $\left(\mathrm{NO}_{\mathrm{x}}: \mathrm{NO}_{3}{ }^{-}+\right.$ $\mathrm{NO}_{2}{ }^{-}$, ammonium: $\mathrm{NH}_{4}{ }^{+}$, phosphate: $\mathrm{PO}_{4}{ }^{3-}$, and, only for diatoms, silicate: $\mathrm{Si}$ ). Integrated levels of temperature and salinity were acquired through the daily CTD casts performed in 
313 each mesocosm. $\mathrm{NO}_{\mathrm{x}}$ and phosphate were measured using nanomolar techniques as described

314 in Louis et al. (in press, this issue). Ammonium and silicate concentrations were determined

315 as described by Gazeau et al. (in press, this issue). As fully described in Gazeau et al. (in

316 press, this issue), daily $\mathrm{pCO}_{2}$ levels in each mesocosm were determined from dissolved

317 inorganic carbon, total alkalinity, temperature and salinity using the R package seacarb

318 (Lavigne et al., 2014).

319 All analyses were performed using the R software (R Core Team, 2015) and were

320 considered significant at a probability $p<0.01$. 


\section{Results}

\subsection{Environmental and experimental conditions during both experiments}

Conditions in each mesocosm at the start and at the end of both experiments (days 0 and 20 in the Bay of Calvi and days 0 and 12 in the Bay of Villefranche) are shown in Tables 2 and 3. For both experiments, $p \mathrm{CO}_{2}$ values in $\mathrm{CO}_{2}$-enriched mesocosms ( $\mathrm{P} 1$ to $\mathrm{P} 6$ ) were close to targeted levels. Ambient $p \mathrm{CO}_{2}$ levels were higher in the Bay of Calvi in summer as compared to the Bay of Villefranche in winter ( 450 vs. $350 \mu$ atm respectively). While $p \mathrm{CO}_{2}$ levels slightly decreased ( $\mathrm{pH}$ levels slightly increased) in the Bay of Calvi during the course of the experiment, especially for high $\mathrm{CO}_{2}$ mesocosms ( $\mathrm{P} 5$ and $\mathrm{P} 6$ ), drops in $p \mathrm{CO}_{2}$ levels

330 (increases in $\mathrm{pH}$ levels) were much stronger in the Bay of Villefranche with mesocosms P1 to P4 showing very similar levels by the end of the experiment (Fig. 1). Hydrological data (temperature and salinity) are fully described in Gazeau et al. (in press, this issue). Briefly, while temperature levels in the Bay of Calvi gradually increased from $\sim 22.1{ }^{\circ} \mathrm{C}$ on day 0 to $\sim 24.2{ }^{\circ} \mathrm{C}$ on day 20 , they were constant in the Bay of Villefranche at around $\sim 13.2{ }^{\circ} \mathrm{C}$. Salinity increased roughly by 0.1-0.2 units during both experiments because of evaporation. In winter in the Bay of Villefranche, surface irradiance was generally constant during the entire experiment with minimal and maximal daily (sunrise to sunset) average values of 531 and $735 \mu \mathrm{mol}$ photons $\mathrm{m}^{-2} \mathrm{~s}^{-1}$. Maximum irradiance levels $\left(\sim 1300-1400 \mu \mathrm{mol}\right.$ photons $\mathrm{m}^{-2} \mathrm{~s}^{-1}$ were reached at around 12:00 pm and the Light:Darkness (L:D) cycle was 16.5:7.5 and 16:8,

340 respectively at the start and at the end of the experiment. In the Bay of Villefranche, minimal 341 and maximal daily (sunrise to sunset) average values of 103 and $513 \mu \mathrm{mol}$ photons $\mathrm{m}^{-2} \mathrm{~s}^{-1}$

342 were recorded with a L:D regime of 11.5:12.5, and maximal irradiance levels ( $300-1100$ $343 \mu \mathrm{mol}$ photons $\mathrm{m}^{-2} \mathrm{~s}^{-1}$ ) reached at 1:00 $\mathrm{pm}$. Light attenuation coefficients were generally 344 constants during both experiments with higher values estimated in winter in the Bay of 345 Villefranche than in summer in the bay of Calvi $\left(0.19 \pm 0.07 \mathrm{SD}\right.$ and $0.14 \pm 0.05 \mathrm{SD} \mathrm{m}^{-1}$, 
respectively). Higher daily averaged wind speeds were recorded during the winter experiment in the Bay of Villefranche with very windy conditions experienced on day 8 that prevented sampling during that day, and even winder on day 12 and the following night that irreversibly 349 damaged the bags.

In summer in the Bay of Calvi, $\mathrm{NO}_{\mathrm{x}}$ concentrations initially decreased then increased agin after day 14 to reach similar levels than at the start of the experiment $(47 \pm 20$ on day 0 vs. $60 \pm 15 \mathrm{nmol} \mathrm{L} \mathrm{L}^{-1}$ on day 20; average $\pm \mathrm{SD}$ between the nine mesocosms). Dissolved inorganic phosphate $\left(\mathrm{PO}_{4}{ }^{3-}\right)$ quickly decreased from day 0 to day 1 and remained constant during the rest of the experiment ( $23 \pm 12$ on day 0 vs. $7 \pm 2 \mathrm{nmol} \mathrm{L}^{-1}$ on day 20). In winter in the Bay of Villefranche, $\mathrm{PO}_{4}{ }^{3-}$ concentrations were generally similar to the ones encountered in summer in the Bay of Calvi and no strong variations could be observed in all mesocosms along the course of the experiment (global average: $9 \pm 1 \mathrm{nM}$ ). $\mathrm{NO}_{\mathrm{x}}$ levels were much higher in the Bay of Villefranche than in the Bay of Calvi when bags were closed (> $1 \mu \mathrm{M})$. However, during the acidification phase (day-4 to -1), due to favorable weather conditions

360 (low wind, high irradiance levels, data not shown), chlorophyll $a$ concentrations increased, 361 consuming a large proportion of available nitrate and nitrite before the start of the 362 experimental phase (day 0 ). As a consequence, while $\left[\mathrm{NO}_{\mathrm{x}}\right]$ in external waters remained high 363 $(\sim 1 \mu \mathrm{M})$, all mesocosms were depleted in $\mathrm{NO}_{\mathrm{x}}$ with an average concentration of $129 \pm 30$ nM. $\mathrm{NO}_{\mathrm{x}}$ to phosphate ratios were higher in the Bay of Villefranche than in the Bay of Calvi $365(2 \pm 1$ and $9 \pm 4$ on day 0 and on day 20 in the Bay of Calvi vs. $13 \pm 4$ and $33 \pm 18$ on day 0 366 and on day 12 in the Bay of Villefranche). More details on nutrient dynamics can be found in 367 Louis et al. (in press, this issue). The experiment in the Bay of Calvi was representative of summer conditions in the 369 Ligurian Sea with low nutrient concentrations, low chlorophyll $a$ concentrations (see below), 370 warm waters and high irradiance levels. In the Bay of Villefranche in winter, while 
hydrological and weather conditions were typical of winter conditions in the Northwestern

372 Mediterranean Sea (low temperature and irradiance levels), nutrients were rapidly depleted

373

374 inside the mesocosms before the start of the experiment, and reached levels not usually encountered during this period of the year.

\subsection{Phytoplankton assemblages during the summer experiment in the Bay of Calvi}

Total chlorophyll $a$ concentrations in the Bay of calvi (Fig. 2) averaged $0.07 \pm 0.01 \mu \mathrm{g}$ $\mathrm{L}^{-1}$ in the nine mesocosms along the experiment, a value much lower than that in the surrounding waters $\left(0.12 \pm 0.02 \mu \mathrm{g} \mathrm{L}{ }^{-1}\right)$. In mesocosms, chlorophyll $a$ concentrations linearly increased during the experiment $\left(\mathrm{GLM}, \mathrm{r}^{2}=0.6, \mathrm{p}<0.001\right)$ with a maximal concentration of $0.09 \pm 0.003 \mu \mathrm{g} \mathrm{L}{ }^{-1}$ on day 14 .

When pigment data for all mesocosms were pooled together (Fig. 3), the plankton community in the Bay of Calvi was found to be dominated at the start of the experiment by haptophyceae representing $36 \pm 5 \%$ of the chlorophyll content, followed by cyanophyceae (20 $\pm 3 \%)$, chlorophyceae $(14 \pm 3 \%)$ and pelagophyceae $(11 \pm 2 \%)$. Important differences were identified along the experiment between concentrations of the different species inside the mesocosms and in the surrounding waters (Fig. 4). All species, except for diatoms, showed lower chlorophyll $a$ biomass inside mesocosms. Diatoms were virtually absent in the surrounding waters, except at the end of the experiment. On day 20, while the contribution of cyanophyceae, dinophyceae, diatoms, pelagophyceae and cryptophyceae did not strongly change as compared to day 0 , the contribution of chlorophyceae increased to $31 \pm 4 \%$. Based on flow cytometry measurements, Synechococcus abundances increased during the first days of the experiment, reached maximal values on day 10 (averaged between mesocosms of $29600 \pm 3000$ cells $\mathrm{mL}^{-1}$ ) and then decreased until the end of the experiment (Fig. 5). Similar dynamics, although with more variability among mesocosms, were observed 
for autotrophic pico-eukaryotes, with abundances one order of magnitude lower than Synechococcus.

Table 4 shows total chlorophyll $a$ concentrations were not correlated with $p \mathrm{CO}_{2}$ but showed positive trends with salinity and to a lesser extent with $\mathrm{NH}_{4}{ }^{+}$. Chlorophyll $a$ equivalent biomass of two groups of phytoplankton were significantly correlated with $p \mathrm{CO}_{2}$, dinophyceae and haptophyceae. For these two groups, $p \mathrm{CO}_{2}$ appeared as the most important contributor to the variance. Note that a maximum of $66 \%$ of the variance (i.e. for chlorophyceae) observed in total chlorophyll $a$ or group-specific biomasses could be explained by these stepwise linear regression analyses using the tested environmental and/or experimental variables.

\subsection{Phytoplankton assemblage during the winter experiment in the Bay of Villefranche}

In the Bay of Villefranche (Fig. 2), total chlorophyll $a$ concentrations averaged $0.98 \pm$ $0.15 \mu \mathrm{g} \mathrm{L}^{-1}$ in the nine mesocosms along the 12-day experiment. Chlorophyll $a$ remained slightly above levels in the surrounding waters for the entire experimental period, except for the last day (day 12) when concentrations increased abruptly outside the mesocosms. HPLC data are available for the acidification phase of this experiment (day -4 to day -1 ), data show that chlorophyll $a$ concentrations increased during that period, consuming a large proportion of available nutrients, notably nitrate and nitrite, before the start of the experimental phase (see 3.1). In all mesocosms, after this initial peak, chlorophyll $a$ concentrations linearly decreased until the end $\left(\mathrm{GLM}, \mathrm{r}^{2}=0.8, \mathrm{p}<0.001\right)$.

When pigment data for all mesocosms were pooled together (Fig. 3), the plankton community in the Bay of Villefranche was dominated at the start of the experiment by cryptophyceae representing $26 \pm 1 \%$ of the chlorophyll $a$ content and by haptophyceae at the end (32 $\pm 5 \%)$. Following total chlorophyll $a$ dynamics, almost all groups declined in terms of chlorophyll $a$ equivalent biomass during the 12-day experiment except for cyanophyceae 
whose biomass almost doubled between days 0 and 12 (Fig. 6). Groups that increased during

421 the acidification phase and consumed available nitrate and nitrite belonged to cryptophyceae, haptophyceae, pelagophyceae and cyanophyceae. While pelagophyceae biomass remained constant throughout the experiment, cryptophyceae biomass linearly declined and haptophyceae showed maximal biomass on days 2 and 4 and then slightly declined. Several groups did not follow the initial chlorophyll $a$ increase during the acidification phase (diatoms, dinophyceae, prasinophyceae and chlorophyceae). abundances significantly increased during the acidification phase and reached values much above environmental (external) levels (Fig. 7). After few days of stagnation (days 0 to 6), abundances further increased to maximal values on day 12 (averaged between mesocosms of $42600 \pm 3000$ cells $\mathrm{mL}^{-1}$ ). In contrast, it appears that Prochlorococcus took less advantage of this initial acidification phase with abundances on day 0 similar to external levels. After a small initial decline, abundances increased during the entire experiment with increasing variability between mesocosms. While autotrophic nano-eukaryotes abundance increased before the start of the experiment to levels much higher on day 0 than in the surrounding waters, no difference could be observed for autotrophic pico-eukaryotes on day 0 between mesocosms and the surrounding waters. Autotrophic pico-eukaryote abundance decreased 438 until day 5 , with very low variability between mesocosms, and increased until the end of the experiment with much larger discrepancy between mesocosms. In contrast, abundances of 440 autotrophic nano-eukaryotes decreased almost linearly between day 0 and 12 with a large 441 inter-mesocosm variability throughout the experiment.

Table 4 shows that the chlorophyll $a$-equivalent biomass of haptophyceae and diatoms

443 were significantly correlated with $p \mathrm{CO}_{2}$, although for none of these species $p \mathrm{CO}_{2}$ appeared as 444 the most important contributor to the variance. While haptophyceae appeared negatively 
correlated to $p \mathrm{CO}_{2}$, diatoms were positively correlated to this variable. Note that for these two groups, less than half of the variance could be explained by these multiple regressions. For most of the tested variables, salinity appeared as the most important co-variable, being either positively or negatively correlated to them. As already mentioned, salinity increased gradually variables.

\subsection{Particulate organic matter and export}

In the Bay of Calvi, particulate $\mathrm{C}$ and $\mathrm{N}$ concentrations were very low and close to the analyzer detection limit (respectively, $2.9-7.4 \mu \mathrm{mol} \mathrm{C} \mathrm{L}{ }^{-1}$ and $0.4-1.3 \mu \mathrm{mol} \mathrm{N} \mathrm{L}{ }^{-1}$ ). C:N ratio of the particulate organic matter remained constant in the mesocosms throughout the experiment $(7.0 \pm 1.0)$ and very close to ambient conditions (7.1 \pm 0.7 ; Fig. 2). In the Bay of

Villefranche, higher POC an PON concentrations were measured (respectively, 7.9 - 20.2 $\mu \mathrm{mol} \mathrm{C} \mathrm{L} \mathrm{L}^{-1}$ and $1.0-2.3 \mu \mathrm{mol} \mathrm{N} \mathrm{L} \mathrm{L}^{-1}$ ). As in the Bay of Calvi, $\mathrm{C}: \mathrm{N}$ ratio of the particulate organic matter remained constant in the mesocosms throughout the experiment $(7.5 \pm 0.9)$ and lower than in the surrounding environment (12.9 \pm 4.3 ; Fig. 2$)$. During both experiments, none of the measured variables (POC, PON or POC:PON) displayed any observable dependence on seawater acidification (Table 4). both experiments, although more visible in the Bay of Calvi, organic matter export rates were maximal at the start of the experiments and gradually decreased until the end of the experiments. Much more variability was observed in the Bay of Villefranche with higher exported quantities of organic matter. In the Bay of Calvi, exported C:N ratios were generally homogeneous between mesocosms at the start of the experiment and much more variability was observed towards the end. Stepwise linear regressions showed no $p \mathrm{CO}_{2}$ effects on these export fluxes (Table 4). 


\section{Discussion}

The overall objective of our study was to evaluate the response of the phytoplankton community, particulate organic matter dynamics and export to $p \mathrm{CO}_{2}$ changes in the NW Mediterranean Sea under contrasted physico-chemical (e.g. hydrology, nutrients and irradiance) and biological conditions (assemblage composition and abundance).

Unfortunately, both summer and winter experiments were conducted under nutrient limiting conditions on plankton communities dominated by small species.

The summer experiment in the Bay of Calvi was conducted under typical stratified summer conditions characterized by very low nutrient and chlorophyll concentrations and surface irradiance levels of $\sim 1,400 \mu \mathrm{mol}$ photons $\mathrm{m}^{-2} \mathrm{~s}^{-1}$, corresponding to maximal yearly values in that area (data not shown). With respect to nutrient availability, as fully discussed by (Louis et al., in press, this issue), observed $\mathrm{NO}_{\mathrm{x}}$ and phosphate depleted conditions during the experiment are in the range of usually observed values in the oligotrophic Mediterranean Sea in summer. At the start of the experiment, inorganic N:P ratio was 1.7 and increased up to $\sim 4$ in the mesocosms on day 20. Both a low N:P ratio and low nutrient concentrations suggest that this system experienced $\mathrm{N}$ and $\mathrm{P}$ co-limitation during this period (Louis et al., in press, this issue). During this experiment, the plankton community was clearly dominated by small phytoplankton cells such as haptophyceae, cyanobacteria and chlorophyceae. Similar conditions were reported in this area at this period of the year. Using the same mesocosm setup, Giovagnetti et al. (2013) showed that the summer plankton community was dominated by pico-phytoplankton, representing $~ 70 \%$ of total biomass and composed mostly of haptophyceae and cyanobacteria. The same experiment showed that nano- and microphytoplankton ( $30 \%$ of total biomass) were composed of haptophyceae, chlorophyceae and dinoflagellates. During our experiment, phytoplankton biomass decreased during the 
acidification phase in all mesocosms, independently of $p \mathrm{CO}_{2}$ conditions, as shown by

fluorometric data acquired using daily CTD profiles (Gazeau et al., in press, this issue). This

corresponded to important organic matter sedimentation at the start of the experiment (first

changes in the proportions of the different groups investigated were observed, at the exception

At the end of our experiment and considering the averaged composition in all nine

mesocosms, dominance shifted towards chlorophyceae, in contrast to the external water

potentially due to wall growth. Indeed, a strong wind and wave event prevented sampling on day 19 (Gazeau et al., in press, this issue). On day 20 (our final sampling day), concentrations in chlorophyceae (but also diatoms) increased significantly $(+30 \%)$. This observed increase was likely due to mesocosm shaking from wave actions, that released periphyton (i.e. species growing on the wall of the mesocosms) in the water column. Large species such as diatoms represented less than $\sim 10 \%$ of phytoplankton biomass by the end of the experiment, although

510 biomasses were usually above those in external waters $\left(\sim 5\right.$ vs. $\left.<1 \mathrm{ng} \mathrm{L}^{-1}\right)$. Obviously, this

511 does not appear as a surprise, as it is well known that, during the summer stratified period,

512 diatoms are outcompeted by small species, better adapted to low nutrient and high irradiance

513 levels, and usually do not represent more than $10 \%$ of the phytoplankton biomass in surface

514 waters of the Ligurian Sea (Navarro et al., 2014).

The winter experiment conducted in the Bay of Villefranche was carried out in order

516 to test for $\mathrm{CO}_{2}$ enrichment effects on a Mediterranean plankton community not limited by

517 nutrient availability. However, as a consequence of very favorable weather conditions during 518 a short time window, much of the temporal dynamics observed during the experiment was 
concentrated during the first few days before the end of the acidification process and nutrients

were rapidly consumed in the mesocosms. At the start of the experiment, when targeted $p \mathrm{CO}_{2}$

levels were reached, most of the available $\mathrm{NO}_{\mathrm{x}}$ was already consumed and irradiance

conditions dropped significantly (Gazeau et al., in press, this issue) precluding the formation

of a real bloom in the bags. Addition of nutrients would have then been necessary to activate

forced to end the experiment after 12 days as a consequence of very bad weather conditions.

In the Bay, as a consequence of intense vertical mixing, chlorophyll concentrations have been

maintained at a lower level while nutrients have been continuously replenished (Louis et al.,

in press, this issue). In addition to probably not reflecting properly light conditions (Gazeau et

al., in press, this issue), the isolation of a water mass and the reduction of mixing certainly

does appear as a pitfall of this mesocosm approach or of any incubation system in these

ecosystems which dynamics is strongly linked to physico-chemical conditions (e.g. mixing,

irradiance). As such, results obtained during this experiment must be taken with extreme

caution because of conditions inside the mesocosms not fully reflecting winter conditions in

534 this area. Nevertheless, in winter in the Bay of Villefranche, phytoplankton biomass was

535 much higher than in summer in the Bay of Calvi with values around $1 \mu \mathrm{g} \mathrm{L}^{-1}$ and a clear

536 dominance of small species such as haptophyceae, cryptophyceae and pelagophyceae (> $65 \%$

537 of chlorophyll $a$-equivalent biomass). Previous observations at the entrance of the Bay of

538 Villefranche have shown that the spring phytoplankton bloom usually takes place in

539 February-March and is dominated by pico-nano-phytoplankton (Thyssen et al., 2014).

540 Although not always observed, this first bloom is followed by a second one in May that is

541 dominated by diatoms and large dinoflagellates (Bustillos-Guzmán et al., 1995; Gomez and

542 Gorsky, 2003). During this year 2013, the highest annual chlorophyll $a$ concentrations were

543 reached later than observed in previous years (Gazeau et al., in press, this issue). Our 
544 experiment therefore coincided with pre-bloom conditions although, again, nutrients were

545 rapidly consumed in the mesocosms. Community composition did not drastically change

546 during the course of the experiment inside the mesocosms but small phytoplankton species

547 took advantage of the first few days of the experiment and are likely responsible for the strong

548 consumption of $\mathrm{NO}_{\mathrm{x}}$ during the acidification phase (Louis et al., in press, this issue). In

549 contrast, diatoms and dinoflagellates did not take advantage of the closing of the bags and of

550 favorable weather conditions during these first few days and continuously decreased in

551 abundance until the end of the experiment. This is not a surprise since these species are

552 known to be outcompeted by smaller phytoplankton cells when nutrient limitation is

553 temporally relieved after the winter vertical mixing (Bustillos-Guzmán et al., 1995). Instead

554 of these species, autotrophic prokaryotes, especially Synechococcus, appeared to benefit from

555 the closing of the bags, as their abundance was 3-fold higher than the ambient levels and kept

556 increasing throughout the experiment. While autotrophic nano-eukaryotes decreased in

557 abundance after the initial chlorophyll $a$ increase during the acidification phase, autotrophic

558 pico-eukaryotes benefited from the recycled nutrient pool, as a consequence of increasing

559 bacterial abundance (Celussi et al., in press, this issue), and increased in number during the

560 second part of the experiment.

During these two experiments, while total chlorophyll $a$ concentrations appeared

correlated to environmental conditions (e.g. nutrients, irradiance, salinity) and/or with time,

no significant correlations were found with $\mathrm{pCO}_{2}$. Similarly, we could not evidence any

564 relationship between $p \mathrm{CO}_{2}$ and POC or PON concentrations as well as organic carbon and

565 nitrogen export to the sediment traps. When phytoplankton groups were analysed separately,

566 positive effects were found for haptophyceae and autotrophic dinoflagellates in the Bay of

567 Calvi during the oligotrophic summer period, similarly to what was found during a large in

568 situ mesocosm experiment in the Arctic (Schulz et al., 2013). In winter in the Bay of 
Villefranche, while haptophyceae were negatively correlated with $p \mathrm{CO}_{2}$, diatoms appeared

570 positively impacted, although for these two groups it must be stressed that $\mathrm{CO}_{2}$ was not the

571 first parameter driving their variance. Such positive $\mathrm{CO}_{2}$-effects as observed in summer on

572 haptophyceae and autotrophic dinoflagellates are not surprising, as these species do not

573 possess very efficient CCMs (Reinfelder, 2011). Although cyanobacteria (including

574 Synechococcus) appeared to benefit from our experimental conditions and from the very

575 limited amount of nutrients, they were not impacted by $\mathrm{CO}_{2}$-enrichment. These results are

576 consistent to what was observed by Lomas et al. (2012) in the subtropical North Atlantic but

577 stand in contrast to the negative impact of ocean acidification on Synechococcus abundance

578 observed by Paulino et al. (2008) in a North Sea Fjord under very different trophic and

579 experimental conditions compared to our experiments (i.e. higher chlorophyll levels as well as

580 and enrichment with $\mathrm{N}$ and P). As suggested by Lomas et al. (2012), the response of

581 cyanobacteria might be indirect and controlled by other variables such as nutrients.

All in all, the short-term addition of $\mathrm{CO}_{2}$ in our nutrient-limited systems did not

induce any clear effect on community composition based on pigment analysis. It must be

stressed that these analyses do not allow detecting potential modifications/replacements at the

specific or at the intra-specific level as suggested by several studies in the recent years

586 (Brading et al., 2011; Rickaby et al., 2016). Nevertheless, scanning electron microscopy

analyses reported by (Oviedo et al., in press, this issue) did not highlight any changes in

coccolithophores and siliceous phytoplankton community compositions, and especially any

changes in species size that could have an impact on sedimentation rates (Feng et al., 2010;

590 Tortell et al., 2008; Wu et al., 2014). During our experiments, no phylogenetic studies have

591 been conducted at the exception of diazotrophs during the summer in the Bay of Calvi (Rees

592 et al., in press, this issue). For this group, no significant changes could be evidenced. In the

593 present study, the small positive or negative effects that have been highlighted on selected 
594 groups based on pigment analyses appear to be minimal and did not lead to significant

595 changes in terms of community metabolism (Maugendre et al., in press, this issue-b), bacterial 596 production (Celussi et al., in press, this issue), carbon transfer (Maugendre et al., in press, this 597 issue-a) as well as carbon and nitrogen export (this study). These results clearly stand in contrast to recent experiments conducted in a coastal site in the Western Mediterranean Sea, using indoor tanks (Sala et al., 2016). Similar to our

600 planned experimental protocol, two experiments were conducted under contrasting 601 conditions: winter, at the peak of the annual phytoplankton bloom, and summer, under low nutrient conditions. Their results suggested microbial communities will be considerably more affected by ocean acidification under oligotrophic conditions than in more productive waters. It must be stressed that even during their summer low-nutrient experiment, reported nitrate concentrations were almost ten times higher than concentrations observed in summer in the

606 Bay of Calvi and four times higher than observed in the Bay of Villefranche in the mesocosms at the end of the acidification period. Similarly, chlorophyll concentrations during our summer experiment were three times lower than observed by Sala et al. (2016) in summer in the Bay of Blanes. Recently, two other experiments conducted using large in situ mesocosms also suggested that communities in nutrient-limited areas may be more responsive

611 to changing carbonate chemistry than those having access to high inorganic nutrient concentrations (Bach et al., 2016; Paul et al., 2015a). These two experiments, sharing a similar experimental protocol than in the present study, were conducted over significantly

614 longer time scales (> 43 days). During both experiments, impacts of elevated $\mathrm{CO}_{2}$ were 615 visible during the last phase when plankton communities were relying on remineralized 616 nutrients. As both our experiments did not exceed $\sim 20$ days, the build-up of remineralized 617 nutrients did not reach concentrations high enough to significantly relieve the nutrient 618 limitation. Nutrient limitation can be episodically relieved in summer through atmospheric 
inputs (The Mermex group, 2011 and references therein) and it is now well known that pulsed

620 atmospheric nutrient inputs enhance phototrophic, heterotrophic and diazotrophic activities

621 (Guieu et al., 2014). It appears therefore of the utmost importance to target future experimental efforts on the response of summer plankton communities to ocean acidification in the case of a transient relieve in nutrient limitation through of a dust deposition event.

\section{5. Conclusion}

To conclude, for the first time, short-term in situ pelagic mesocosm experiments have been conducted in LNLC areas of the Northwestern Mediterranean Sea to assess the response of phytoplankton communities to ocean acidification. In contrast to most previous mesocosm experiments, no nutrient addition took place during the experiments conducted in summer and winter. The summer plankton community was dominated by pico-phytoplankton and cyanobacteria and was strongly limited by $\mathrm{NO}_{\mathrm{x}}$ and phosphate availability. Although, haptophyceae and autotrophic dinoflagellates appeared to be favored by increased $\mathrm{CO}_{2}$ availability during this short-term experiment, this benefit remained very minimal with no impact on carbon export, as a consequence of strong environmental constraints. The winter community was also dominated by small species (especially haptophyceae and cryptophyceae) that reacted soon after closing the bags and during the acidification period, possibly due to favorable weather conditions and irradiance levels. During this experiment, no signs of short term $\mathrm{CO}_{2}$ addition dependency were detected on plankton community structure

638 based on pigment analyses and on organic matter export. As a consequence of the very

639 dynamic nature of environmental conditions and therefore of plankton biomass and

640 composition in the Mediterranean Sea, more investigations are needed to carefully assess the 641 response of plankton communities in winter when vertical mixing and weather conditions are major factors controlling plankton dynamics in this area. Future experimental protocols might 
643 consider maintaining nutrient and chlorophyll levels as close as possible to ambient

644 conditions over longer time scales. Although this might be experimentally challenging, we

645 believe this is the only way to investigate these very dynamic communities. Finally, as

646 atmospheric depositions in summer have the capacity to relieve nutrient limitations and to

647 enhance plankton productions, there is a great need to perform future experiments considering 648 these pulsed nutrient additions. 
649

650

651

652

653

654

655

656

657

658

659

660

661

662

663

664

665

666 acknowledged for his help on CHEMTAX analyses.

\section{Acknowledgements}

This work was funded by the EC FP7 project 'Mediterranean Sea Acidification in a changing climate' (MedSeA; grant agreement 265103), the project 'European Free Ocean

Carbon Enrichment' (eFOCE; BNP-Paribas Foundation), the MISTRALS-MERMEX program (Institut des Sciences de l'Univers, INSU), the Corsican local authorities and the Rhone-Mediterranean and Corsica Water Agency (http://www.eaurmc.fr). It is a contribution to the Surface Ocean-Lower Atmosphere Study (SOLAS) and Integrated Marine Biogeochemistry and Ecosystem Research (IMBER) projects. The STARESO marine station in Corsica is gratefully acknowledged for its assistance and boat support carried out within the framework of the STARECAPMED project funded by the Rhone-Mediterranean and Corsica Water Agency. B. Cataletto, F. Cerino, C. Comici, W. Dellisanti and C. Fabbro are acknowledged for sample preparation and analyses of particulate organic carbon and nitrogen. The staff of the Observatoire Océanologique de Villefranche is gratefully acknowledged for their assistance and boat support, colleagues of the Laboratoire d'Océanographie de Villefranche for providing laboratory space. S. Alliouane, B. Hesse, D. Luquet, D. Robin, P. Mahacek and E. Cox are acknowledged for assistance with diving operations. Thanks are due to all the MedSeA mesocosm team for help during the experiments. Finally, C. Brunet is 
667

668

669

670

671

672

673

674

675

676

677

678

679

680

681

682

683

684

685

686

687

688

689

690

\section{References}

Bach, L.T., Taucher, J., Boxhammer, T., Ludwig, A., Achterberg, E.P., Algueró-Muñiz, M., Anderson, L.G., Bellworthy, J., Büdenbender, J., Czerny, J., Ericson, Y., Esposito, M., Fischer, M., Haunost, M., Hellemann, D., Horn, H.G., Hornick, T., Meyer, J., Sswat, M., Zark, M., Riebesell, U., The Kristineberg, K.C., 2016. Influence of Ocean Acidification on a Natural Winter-to-Summer Plankton Succession: First Insights from a Long-Term Mesocosm Study Draw Attention to Periods of Low Nutrient Concentrations. PLoS ONE 11, e0159068.

Badger, M.R., Andrews, T.J., Whitney, S.M., Ludwig, M., Yellowlees, D.C., Leggat, W., Price, G.D., 1998. The diversity and coevolution of Rubisco, plastids, pyrenoids, and chloroplast-based $\mathrm{CO}_{2}$-concentrating mechanisms in algae. Canadian Journal of Botany-Revue Canadienne De Botanique 76, 1052-1071.

Brading, P., Warner, M.E., Davey, P., Smith, D.J., Achterberg, E.P., Suggett, D.J., 2011. Differential effects of ocean acidification on growth and photosynthesis among phylotypes of Symbiodinium (Dinophyceae). Limnol. Oceanogr. 56, 927-938.

Brussaard, C.P.D., Noordeloos, A.A.M., Witte, H., Collenteur, M.C.J., Schulz, K.G., Ludwig, A., Riebesell, U., 2013. Arctic microbial community dynamics influenced by elevated $\mathrm{CO}_{2}$ levels. Biogeosciences 10, 719-731.

Bustillos-Guzmán, J., Claustre, H., Marty, J.C., 1995. Specific phytoplankton signatures and their relationship to hydrographic conditions in the coastal Northwestern Mediterranean Sea. Marine Ecology Progress Series 124, 247-258.

Calbet, A., Sazhin, A.F., Nejstgaard, J.C., Berger, S.A., Tait, Z.S., Olmos, L., Sousoni, D., Isari, S., Martinez, R.A., Bouquet, J.M., Thompson, E.M., Bamstedt, U., Jakobsen, H.H., 2014. Future climate scenarios for a coastal productive planktonic food web 
resulting in microplankton phenology changes and decreased trophic transfer efficiency. Plos One 9.

693

694

695

696

697

698

699

700

701

702

703

704

705

706

707

708

709

710

Celussi, M., Malfatti, F., Franzo, A., Gazeau, F., Giannakourou, A., Pitta, P., Tsiola, A., Del Negro, P., in press, this issue. Ocean acidification effect on prokaryotic metabolism in two different locations in the Mediterranean Sea. Estuarine, Coastal and Shelf Science.

Ciais, P., Sabine, C., Bala, G., Bopp, L., Brovkin, V., Canadell, J., Chhabra, A., DeFries, R., Galloway, J., Heimann, M., Jones, C., Le Quéré, C., Myneni, R.B., Piao, S., Thornton, P., 2013. Carbon and Other Biogeochemical Cycles, in: Stocker, T.F., Qin, D., Plattner, G.-K., Tignor, M., Allen, S.K., Boschung, J., Nauels, A., Xia, Y., Bex, V., Midgley, P.M. (Eds.), Climate Change 2013: The Physical Science Basis. Contribution of Working Group I to the Fifth Assessment Report of the Intergovernmental Panel on Climate Change, Cambridge University Press, Cambridge, United Kingdom and New York, NY, USA.

Claustre, H., Kerherve, P., Marty, J.C., Prieur, L., Videau, C., Hecq, J.H., 1994. Phytoplankton dynamics associated with a geostrophic front - ecological and biogeochemical implications. Journal of Marine Research 52, 711-742.

Czerny, J., Schulz, K.G., Boxhammer, T., Bellerby, R.G.J., Büdenbender, J., Engel, A., Krug, S.A., Ludwig, A., Nachtigall, K., Nondal, G., Niehoff, B., Silyakova, A., Riebesell, U., 2013. Implications of elevated $\mathrm{CO}_{2}$ on pelagic carbon fluxes in an Arctic mesocosm study - an elemental mass balance approach. Biogeosciences 10, 3109-3125.

D'Ortenzio, F., d'Alcala, M.R., 2009. On the trophic regimes of the Mediterranean Sea: a satellite analysis. Biogeosciences 6, 139-148.

Domingues, R.B., Guerra, C.C., Barbosa, A.B., Brotas, V., Galvao, H.M., 2014. Effects of ultraviolet radiation and $\mathrm{CO}_{2}$ increase on winter phytoplankton assemblages in a temperate coastal lagoon. Journal of Plankton Research 36, 672-684. 
Dutkiewicz, S., Morris, J.J., Follows, M.J., Scott, J., Levitan, O., Dyhrman, S.T., BermanFrank, I., 2015. Impact of ocean acidification on the structure of future phytoplankton communities. Nature Climate change 5, 1002-1006.

Eggers, S.L., Lewandowska, A.M., Ramos, J.B.E., Blanco-Ameijeiras, S., Gallo, F., Matthiessen, B., 2014. Community composition has greater impact on the functioning of marine phytoplankton communities than ocean acidification. Global Change Biology 20, 713-723.

Endo, H., Sugie, K., Yoshimura, T., Suzuki, K., 2016. Response of spring diatoms to $\mathrm{CO}_{2}$ availability in the Western North Pacific as determined by next-generation sequencing. PLoS ONE 11, e0154291-e0154291.

Engel, A., Schulz, K.G., Riebesell, U., Bellerby, R., Delille, B., Schartau, M., 2008. Effects of $\mathrm{CO}_{2}$ on particle size distribution and phytoplankton abundance during a mesocosm bloom experiment (PeECE II). Biogeosciences 5, 509-521.

Engel, A., Zondervan, I., Aerts, K., Beaufort, L., Benthien, A., Chou, L., Delille, B., Gattuso, J.P., Harlay, J., Heemann, C., Hoffmann, L., Jacquet, S., Nejstgaard, J., Pizay, M.D., Rochelle-Newall, E., Schneider, U., Terbrueggen, A., Riebesell, U., 2005. Testing the direct effect of $\mathrm{CO}_{2}$ concentration on a bloom of the coccolithophorid Emiliania huxleyi in mesocosm experiments. Limnol. Oceanogr. 50, 493-507.

Feng, Y., Hare, C.E., Rose, J.M., Handy, S.M., DiTullio, G.R., Lee, P.A., Smith, W.O., Peloquin, J., Tozzi, S., Sun, J., Zhang, Y., Dunbar, R.B., Long, M.C., Sohst, B., Lohan, M., Hutchins, D.A., 2010. Interactive effects of iron, irradiance and $\mathrm{CO}_{2}$ on Ross Sea phytoplankton. Deep-Sea Research Part I-Oceanographic Research Papers 57, 368-383. Feng, Y.Y., Hare, C.E., Leblanc, K., Rose, J.M., Zhang, Y.H., DiTullio, G.R., Lee, P.A., Wilhelm, S.W., Rowe, J.M., Sun, J., Nemcek, N., Gueguen, C., Passow, U., Benner, I., Brown, C., Hutchins, D.A., 2009. Effects of increased $p \mathrm{CO}_{2}$ and temperature on the 
North Atlantic spring bloom. I. The phytoplankton community and biogeochemical response. Marine Ecology Progress Series 388, 13-25.

743

Field, C.B., Behrenfeld, M.J., Randerson, J.T., Falkowski, P., 1998. Primary production of the biosphere: integrating terrestrial and oceanic components. Science 281, 237-240.

Finkel, Z.V., Katz, M.E., Wright, J.D., Schofield, O.M.E., Falkowski, P.G., 2005.

Climatically driven macroevolutionary patterns in the size of marine diatoms over the Cenozoic. Proceedings of the National Academy of Sciences of the United States of America 102, 8927-8932.

Flynn, K.J., Blackford, J.C., Baird, M.E., Raven, J.A., Clark, D.R., Beardall, J., Brownlee, C., Fabian, H., Wheeler, G.L., 2012. Changes in $\mathrm{pH}$ at the exterior surface of plankton with ocean acidification. Nature Climate Change, 510-513.

Gattuso, J.P., Magnan, A., Bille, R., Cheung, W.W.L., Howes, E.L., Joos, F., Allemand, D., Bopp, L., Cooley, S.R., Eakin, C.M., Hoegh-Guldberg, O., Kelly, R.P., Poertner, H.O., Rogers, A.D., Baxter, J.M., Laffoley, D., Osborn, D., Rankovic, A., Rochette, J., Sumaila, U.R., Treyer, S., Turley, C., 2015. Contrasting futures for ocean and society from different anthropogenic $\mathrm{CO}_{2}$ emissions scenarios. Science $349,45-+$.

Gazeau, F., Sallon, A., Maugendre, L., Louis, J., Dellisanti, W., Gaubert, M., Lejeune, P., Gobert, S., Borges, A.V., Harlay, J., Champenois, W., Alliouane, S., Taillandier, V., Louis, F., Obolensky, G., Grisoni, J.M., Guieu, C., in press, this issue. First mesocosm experiments to study the impacts of ocean acidification on plankton communities in the NW Mediterranean Sea (MedSeA project). Estuarine, Coastal and Shelf Science.

Giordano, M., Beardall, J., Raven, J.A., 2005. $\mathrm{CO}_{2}$ concentrating mechanisms in algae: Mechanisms, environmental modulation, and evolution, Annual Review of Plant Biology, pp. 99-131. 
Giovagnetti, V., Brunet, C., Conversano, F., Tramontano, F., Obernosterer, I., Ridame, C., Guieu, C., 2013. Assessing the role of dust deposition on phytoplankton ecophysiology and succession in a low-nutrient low-chlorophyll ecosystem: a mesocosm experiment in the Mediterranean Sea. Biogeosciences 10, 2973-2991.

Gomez, F., Gorsky, G., 2003. Annual microplankton cycles in Villefranche Bay, Ligurian Sea, NW Mediterranean. Journal of Plankton Research 25, 323-339.

Guieu, C., Aumont, O., Paytan, A., Bopp, L., Law, C.S., Mahowald, N., Achterberg, E.P., Maranon, E., Salihoglu, B., Crise, A., Wagener, T., Herut, B., Desboeufs, K., Kanakidou, M., Olgun, N., Peters, F., Pulido-Villena, E., Tovar-Sanchez, A., Voelker, C., 2014. The significance of the episodic nature of atmospheric deposition to Low Nutrient Low Chlorophyll regions. Global Biogeochemical Cycles 28, 1179-1198. Hennon, G.M.M., Ashworth, J., Groussman, R.D., Berthiaume, C., Morales, R.L., Baliga, N.S., Orellana, M.V., Armbrust, E.V., 2015. Diatom acclimation to elevated $\mathrm{CO}_{2}$ via cAMP signalling and coordinated gene expression. Nature Clim. Change 5, 761-765.

Hopkins, F.E., Turner, S.M., Nightingale, P.D., Steinke, M., Bakker, D., Liss, P.S., 2010. Ocean acidification and marine trace gas emissions. Proceedings of the National Academy of Sciences of the United States of America 107, 760-765.

Irwin, A.J., Oliver, M.J., 2009. Are ocean deserts getting larger? Geophys. Res. Lett. 36.

Kim, J.H., Kim, K.Y., Kang, E.J., Lee, K., Kim, J.M., Park, K.T., Shin, K., Hyun, B., Jeong, H.J., 2013. Enhancement of photosynthetic carbon assimilation efficiency by phytoplankton in the future coastal ocean. Biogeosciences 10, 7525-7535.

Kim, J.M., Lee, K., Shin, K., Kang, J.H., Lee, H.W., Kim, M., Jang, P.G., Jang, M.C., 2006. The effect of seawater $\mathrm{CO}_{2}$ concentration on growth of a natural phytoplankton assemblage in a controlled mesocosm experiment. Limnol. Oceanogr. 51, 1629-1636. 
Kim, J.M., Lee, K., Shin, K., Yang, E.J., Engel, A., Karl, D.M., Kim, H.C., 2011. Shifts in biogenic carbon flow from particulate to dissolved forms under high carbon dioxide and warm ocean conditions. Geophys. Res. Lett. 38.

Kim, J.M., Lee, K., Yang, E.J., Shin, K., Noh, J.H., Park, K.T., Hyun, B., Jeong, H.J., Kim,

$$
\text { J.H., Kim, K.Y., Kim, M., Kim, H.C., Jang, P.G., Jang, M.C., 2010. Enhanced }
$$
production of oceanic dimethylsulfide resulting from $\mathrm{CO}_{2}$-induced grazing activity in a high $\mathrm{CO}_{2}$ world. Environmental Science \& Technology 44, 8140-8143.

Kroeker, K.J., Kordas, R.L., Crim, R., Hendriks, I.E., Ramajo, L., Singh, G.S., Duarte, C.M., Gattuso, J.P., 2013. Impacts of ocean acidification on marine organisms: quantifying sensitivities and interaction with warming. Global Change Biology 19, 1884-1896.

Lavigne, H., Epitalon, J.M., Gattuso, J.-P., 2014. seacarb: seawater carbonate chemistry with R. ran.r-project.org/package $=$ seacarb.

Lee, C., Wakeham, S.G., Hedges, J.I., 1988. The measurement of oceanic particle flux - Are “swimmers" a problem? Oceanography 1, 34-36.

Lomas, M.W., Hopkinson, B.M., Losh, J.L., Ryan, D.E., Shi, D.L., Xu, Y., Morel, F.M.M., 2012. Effect of ocean acidification on cyanobacteria in the subtropical North Atlantic. Aquatic Microbial Ecology 66, 211-222.

Louis, J., Guieu, C., Gazeau, F., in press, this issue. Nutrient dynamics under different ocean acidification scenarios in a low nutrient low chlorophyll system: the Northwestern Mediterranean Sea. Estuarine, Coastal and Shelf Science. energetic efficiency of the cyanobacterial $\mathrm{CO}_{2}$ concentrating mechanism. Proceedings of the National Academy of Sciences 113, E5354-E5362. 
812 Marie, D., Brussaard, C.P.D., Thyrhaug, R., Bratbak, G., Vaulot, D., 1999. Enumeration of

813

814

815

816

817

818

819

823

826

827

828 marine viruses in culture and natural samples by flow cytometry. Applied and Environmental Microbiology 65, 45-52.

Maugendre, L., Gattuso, J.-P., de Kluijver, A., Soetaert, K., van Oevelen, D., Middelburg, J.J., Gazeau, F., in press, this issue-a. Carbon-13 labelling studies show no effect of ocean acidification on Mediterranean plankton communities. Estuarine, Coastal and Shelf Science.

Maugendre, L., Gattuso, J.P., Poulton, A.J., Dellisanti, W., Gaubert, M., Guieu, C., Gazeau, F., in press, this issue-b. No detectable effect of ocean acidification on plankton metabolism in the NW oligotrophic Mediterranean Sea: Results from two mesocosm studies. Estuarine, Coastal and Shelf Science.

Meakin, N.G., Wyman, M., 2011. Rapid shifts in picoeukaryote community structure in response to ocean acidification. Isme Journal 5, 1397-1405.

Navarro, G., Alvain, S., Vantrepotte, V., Huertas, I.E., 2014. Identification of dominant phytoplankton functional types in the Mediterranean Sea based on a regionalized remote sensing approach. Remote Sensing of Environment 152, 557-575.

Newbold, L.K., Oliver, A.E., Booth, T., Tiwari, B., DeSantis, T., Maguire, M., Andersen, G., van der Gast, C.J., Whiteley, A.S., 2012. The response of marine picoplankton to ocean acidification. Environmental Microbiology 14, 2293-2307.

Not, F., Zapata, M., Pazos, Y., Campana, E., Doval, M., Rodriguez, F., 2007. Sizefractionated phytoplankton diversity in the NW Iberian coast: a combination of microscopic, pigment and molecular analyses. Aquatic Microbial Ecology 49, 255-265.

Oviedo, A.M., Ziveri, P., Gazeau, F., in press, this issue. Coccolithophore dynamics in response to increasing $p \mathrm{CO}_{2}$ in Mediterranean oligotrophic waters. Estuarine, Coastal and Shelf Science. 
Paul, A.J., Bach, L.T., Schulz, K.G., Boxhammer, T., Czerny, J., Achterberg, E.P., Hellemann, D., Trense, Y., Nausch, M., Sswat, M., Riebesell, U., 2015a. Effect of elevated $\mathrm{CO}_{2}$ on organic matter pools and fluxes in a summer Baltic Sea plankton community. Biogeosciences 12, 6181-6203.

Paul, C., Matthiessen, B., Sommer, U., 2015b. Warming, but not enhanced $\mathrm{CO}_{2}$ concentration, quantitatively and qualitatively affects phytoplankton biomass. Marine Ecology Progress Series 528, 39-51.

Paulino, A.I., Egge, J.K., Larsen, A., 2008. Effects of increased atmospheric $\mathrm{CO}_{2}$ on small and intermediate sized osmotrophs during a nutrient induced phytoplankton bloom. Biogeosciences 5, 739-748.

Polovina, J.J., Howell, E.A., Abecassis, M., 2008. Ocean's least productive waters are expanding. Geophys. Res. Lett. 35.

Ras, J., Claustre, H., Uitz, J., 2008. Spatial variability of phytoplankton pigment distributions in the Subtropical South Pacific Ocean: comparison between in situ and predicted data. Biogeosciences 5, 353-369.

Raven, J.A., Beardall, J., 2014. $\mathrm{CO}_{2}$ concentrating mechanisms and environmental change. Aquatic Botany 118, 24-37.

Raven, J.A., Beardall, J., Giordano, M., 2014. Energy costs of carbon dioxide concentrating mechanisms in aquatic organisms. Photosynthesis Research 121, 111-124.

Rees, A.P., Turk-Kubo, K., Al-Moosawi, L., Alliouane, S., Gazeau, F., Hogan, M.E., Zehr, J.P., in press, this issue. Ocean acidification impacts on Mediterranean nitrogen fixation at $p \mathrm{CO}_{2}$ levels indicated for the end of the 21st Century. Estuarine, Coastal and Shelf Science. 
Reinfelder, J.R., 2011. Carbon concentrating mechanisms in Eukaryotic marine phytoplankton, in: Carlson, C.A., Giovannoni, S.J. (Eds.), Annual Review of Marine Science, Vol 3, pp. 291-315.

Reul, A., Munoz, M., Bautista, B., Neale, P.J., Sobrino, C., Mercado, J.M., Segovia, M., Salles, S., Kulk, G., Leon, P., van de Poll, W.H., Perez, E., Buma, A., Blanco, J.M., 2014. Effect of $\mathrm{CO}_{2}$, nutrients and light on coastal plankton. III. Trophic cascade, size structure and composition. Aquatic Biology 22, 59-76.

Richier, S., Achterberg, E.P., Dumousseaud, C., Poulton, A.J., Suggett, D.J., Tyrrell, T., Zubkov, M.V., Moore, C.M., 2014. Phytoplankton responses and associated carbon cycling during shipboard carbonate chemistry manipulation experiments conducted around Northwest European shelf seas. Biogeosciences 11, 4733-4752.

Rickaby, R.E.M., Hermoso, M., Lee, R.B.Y., Rae, B.D., Heureux, A.M.C., Balestreri, C., Chakravarti, L., Schroeder, D.C., Brownlee, C., 2016. Environmental carbonate chemistry selects for phenotype of recently isolated strains of Emiliania huxleyi. Deep Sea Research Part II: Topical Studies in Oceanography 127, 28-40.

Riebesell, U., Bellerby, R.G.J., Grossart, H.P., Thingstad, F., 2008. Mesocosm $\mathrm{CO}_{2}$ perturbation studies: from organism to community level. Biogeosciences 5, 1157-1164.

Riebesell, U., Czerny, J., von Brockel, K., Boxhammer, T., Budenbender, J., Deckelnick, M., Fischer, M., Hoffmann, D., Krug, S.A., Lentz, U., Ludwig, A., Muche, R., Schulz, K.G., 2013a. Technical Note: A mobile sea-going mesocosm system - new opportunities for ocean change research. Biogeosciences 10, 1835-1847.

Riebesell, U., Gattuso, J.P., Thingstad, T.F., Middelburg, J.J., 2013b. Preface "Arctic ocean acidification: pelagic ecosystem and biogeochemical responses during a mesocosm study". Biogeosciences 10, 5619-5626. 
884 Riebesell, U., Schulz, K.G., Bellerby, R.G.J., Botros, M., Fritsche, P., Meyerhofer, M., Neill,

885

886

887

888

889

890

891

892

893

894

895

896

897

898

899

900

901

902

903

904

905

906

907

908

C., Nondal, G., Oschlies, A., Wohlers, J., Zollner, E., 2007. Enhanced biological carbon consumption in a high $\mathrm{CO}_{2}$ ocean. Nature 450, 545-U510.

Riebesell, U., Tortell, P.D., 2011. Effects of ocean acidification on pelagic organisms and ecosystems, in: Gattuso, J.-P., Hansson, L. (Eds.), Ocean acidification. Oxford University Press, Oxford, pp. 99-121.

Rodriguez, F., Garrido, J.L., Crespo, B.G., Arbones, B., Figueiras, F.G., 2006. Sizefractionated phytoplankton pigment groups in the NW Iberian upwelling system: impact of the Iberian Poleward Current. Marine Ecology Progress Series 323, 59-73.

Sala, M.M., Aparicio, F.L., Balagué, V., Boras, J.A., Borrull, E., Cardelús, C., Cros, L., Gomes, A., López-Sanz, A., Malits, A., Martínez, R.A., Mestre, M., Movilla, J., Sarmento, H., Vázquez-Domínguez, E., Vaqué, D., Pinhassi, J., Calbet, A., Calvo, E., Gasol, J.M., Pelejero, C., Marrasé, C., 2016. Contrasting effects of ocean acidification on the microbial food web under different trophic conditions. ICES Journal of Marine Science 73, 670-679.

Sarmiento, J.L., Gruber, N., 2006. Ocean biogeochemical dynamics. Princeton University Press, Princeton, Woodstock.

Schulz, K.G., Bellerby, R.G.J., Brussaard, C.P.D., Budenbender, J., Czerny, J., Engel, A., Fischer, M., Koch-Klavsen, S., Krug, S.A., Lischka, S., Ludwig, A., Meyerhofer, M., Nondal, G., Silyakova, A., Stuhr, A., Riebesell, U., 2013. Temporal biomass dynamics of an Arctic plankton bloom in response to increasing levels of atmospheric carbon dioxide. Biogeosciences 10, 161-180.

Schulz, K.G., Riebesell, U., Bellerby, R.G.J., Biswas, H., Meyerhofer, M., Muller, M.N., Egge, J.K., Nejstgaard, J.C., Neill, C., Wohlers, J., Zollner, E., 2008. Build-up and decline of organic matter during PeECE III. Biogeosciences 5, 707-718. 
Siokou-Frangou, I., Christaki, U., Mazzocchi, M.G., Montresor, M., Ribera d'Alcalá, M., Vaqué, D., Zingone, A., 2010. Plankton in the open Mediterranean Sea: a review. Biogeosciences 7, 1543-1586.

Sommer, U., Paul, C., Moustaka-Gouni, M., 2015. Warming and ocean acidification effects on phytoplankton - From species shifts to size shifts within species in a mesocosm experiment. PLoS ONE 10, e0125239.

Tarling, G.A., Peck, V., Ward, P., Ensor, N.S., Achterberg, E., Tynan, E., Poulton, A.J., Mitchell, E., Zubkov, M.V., 2016. Effects of acute ocean acidification on spatiallydiverse polar pelagic foodwebs: insights from on-deck microcosms. Deep Sea Research Part II: Topical Studies in Oceanography 127, 75-92.

The Mermex group, 2011. Marine ecosystems' responses to climatic and anthropogenic forcings in the Mediterranean. Progress in Oceanography 91, 97-166.

Thyssen, M., Gregori, G.J., Grisoni, J.-M., Pedrotti, M., Mousseau, L., Artigas, L.F., Marro, S., Garcia, N., Passafiume, O., Denis, M.J., 2014. Onset of the spring bloom in the Northwestern Mediterranean Sea: influence of environmental pulse events on the in situ hourly-scale dynamics of the phytoplankton community structure. Frontiers in Microbiology 5.

Tortell, P.D., 2000. Evolutionary and ecological perspectives on carbon acquisition in phytoplankton. Limnol. Oceanogr. 45, 744-750.

Tortell, P.D., DiTullio, G.R., Sigman, D.M., Morel, F.M.M., 2002. $\mathrm{CO}_{2}$ effects on taxonomic composition and nutrient utilization in an Equatorial Pacific phytoplankton assemblage. Marine Ecology Progress Series 236, 37-43.

Tortell, P.D., Payne, C.D., Li, Y.Y., Trimborn, S., Rost, B., Smith, W.O., Riesselman, C., Dunbar, R.B., Sedwick, P., DiTullio, G.R., 2008. $\mathrm{CO}_{2}$ sensitivity of Southern Ocean phytoplankton. Geophys. Res. Lett. 35, 5. 
934 Troussellier, M., Courties, C., Zettelmaier, S., 1995. Flow cytometric analysis of coastal

935 lagoon bacterioplankton and picophytoplankton - fixation and storage effects. Estuarine

$936 \quad$ Coastal and Shelf Science 40, 621-633.

937 Vaulot, D., Courties, C., Partensky, F., 1989. A simple method to preserve oceanic

938 phytoplankton for flow cytometric analyses. Cytometry 10, 629-635.

939 Verspagen, J.M.H., Van de Waal, D.B., Finke, J.F., Visser, P.M., Huisman, J., 2014.

940 Contrasting effects of rising $\mathrm{CO}_{2}$ on primary production and ecological stoichiometry at 941 different nutrient levels. Ecology Letters 17, 951-960.

942 Wu, Y., Campbell, D.A., Irwin, A.J., Suggett, D.J., Finkel, Z.V., 2014. Ocean acidification

943 enhances the growth rate of larger diatoms. Limnol. Oceanogr. 59, 1027-1034.

944 Young, J.N., Heureux, A.M.C., Sharwood, R.E., Rickaby, R.E.M., Morel, F.M.M., Whitney,

945 S.M., 2016. Large variation in the Rubisco kinetics of diatoms reveals diversity among

946 their carbon-concentrating mechanisms. Journal of Experimental Botany.

947 Young, J.N., Morel, F.M.M., 2015. Biological oceanography: The $\mathrm{CO}_{2}$ switch in diatoms.

$948 \quad$ Nature Climate change 5, 722-723. 


\section{$950 \quad$ Figure legends}

951 Figure 1. Carbonate chemistry conditions in the nine mesocosms and in the external environment (OUT) during the experiment in the Bay of Calvi in summer 2012 (left panels) and in the Bay of Villefranche in winter 2013 (right panels). Partial pressure of $\mathrm{CO}_{2}\left(p \mathrm{CO}_{2}\right.$, upper panels) and $\mathrm{pH}$ on the total scale $\left(\mathrm{pH}_{\mathrm{T}}\right.$, lower panels) were calculated using seacarb, based on dissolved inorganic carbon concentrations $\left(C_{\mathrm{T}}\right.$, not shown $)$ and total alkalinity $\left(A_{\mathrm{T}}\right.$, not shown), measured daily from depth-integrated $(0-10 \mathrm{~m})$ samples. Vertical dotted lines show the start of the respective experiments (day 0).

Figure 2. Depth-integrated $(0-10 \mathrm{~m})$ chlorophyll $a$ concentrations as measured by high performance liquid chromatography (HPLC; upper panels) and particulate organic carbon (POC) to particulate organic nitrogen (PON) ratio (POC:PON; lower panels) in the nine mesocosms and in the external environment during the experiment in the Bay of Calvi in summer 2012 (left panels) and in the Bay of Villefranche in winter 2013 (right panels). Vertical dotted lines on the right panels show the start of the experiment (day 0). No chlorophyll $a$ and POC data are available before day 0 in the Bay of Calvi.

Figure 3. Averaged contribution $(\%)$ between all nine mesocosms of the main phytoplanktonic taxonomic groups to total chlorophyll $a$ concentrations at the start (day 0) and at the end (day 20 or 12) of the experiments in the Bay of Calvi in summer 2012 (left panel) and in the Bay of Villefranche in winter 2013 (right panel).

Figure 4. Temporal evolution of chlorophyll $a(\operatorname{chl} a)$-equivalent concentrations of eight taxonomic groups of phytoplankton during the experiment in the Bay of Calvi in summer 2012, in the nine mesocosms and in the external environment (OUT). Prasino: prasinophyceae, Dino: dinophyceae, Crypto: cryptophyceae, Hapto: haptophyceae, Pelago: pelagophyceae, Chloro: chlorophyceae, Cyano: cyanophyceae. 
974 Figure 5. Temporal evolution of Synechococcus and pico-eukaryotes abundances as measured

975

976

977

978

979

980

981

982

983

984

985

986

987

988

989

990

991

992

993

994 by flow cytometry, during the experiment in the Bay of Calvi in summer 2012, in the nine mesocosms.

Figure 6. Temporal evolution of chlorophyll $a(\operatorname{chl} a)$-equivalent concentrations of 8 taxonomic groups of phytoplankton determined from high performance liquid chromatography (HPLC) measurements using modified CHEMTAX, during the experiment in the Bay of Villefranche in winter 2013, in the 9 mesocosms and in the external environment (OUT). Prasino: prasinophyceae, Dino: dinophyceae, Crypto: cryptophyceae, Hapto: haptophyceae, Pelago: pelagophyceae, Chloro: chlorophyceae, Cyano: cyanophyceae.

Figure 7. Temporal evolution of Synechococcus, Prochlorococcus, pico-eukaryotes and nanoeukaryotes abundances as measured by flow cytometry, during the experiment in the Bay of Villefranche in winter 2013, in the nine mesocosms and in the external environment (OUT).

Figure 8. Upper panel: temporal evolution of particulate organic carbon (POC) fluxes to the sediment traps during the experiment in the Bay of Calvi in summer 2012 (left panel) and in the Bay of Villefranche in winter 2013 (right panel). Lower panel: particulate organic carbon (POC) to particulate organic nitrogen (PON) ratio in the sediment traps during the experiment in the Bay of Calvi in summer 2012. No PON data available during the experiment in the Bay of Villefranche in winter 2013. Vertical dotted lines show the start of the respective experiment (day 0). 
995 Table 1. Summary of past mesocosm (volume between 1 and $1000 \mathrm{~m}^{3}$ ) ocean acidification experiments results on phytoplankton communities. $\Leftrightarrow$, 仓 and

$996 \sqrt{3}$ refer to neutral, positive and negative effects on chlorophyll $a$ concentrations (Chl $a$ ) as well as concentrations of diatoms (diat), dinophyceae (Dino),

997 nano-eukaryotes (Nano), pico-eukaryotes (Pico) and cyanophyceae (Cyano). Impacts on carbon export are also reported when available. “ $\sqrt{ }$ ” indicates that

998 mesocosms were enriched with nutrients (Nut: nitrate, phosphate and sometimes silicate). “-“indicates that no information is available. Cryp and Chlo

999 refer to cryptophyceae and chlorophyceae respectively.

\begin{tabular}{|c|c|c|c|c|c|c|c|c|c|c|c|c|}
\hline Reference & Study location & Season & Nut & Major group & Chl & Diat & Dino & Nano & Pico & Cyano & Export & Notes \\
\hline \multicolumn{13}{|l|}{ Indoor } \\
\hline $\begin{array}{l}\text { Sommer et al. (2015) } \\
\text { Paul et al. (2015b) }\end{array}$ & Kiel Bight & Fall & & Diat/Dino & $\Leftrightarrow$ & $\sqrt{ }$ & $\Leftrightarrow$ & & $\Rightarrow$ & $\Leftrightarrow$ & - & \\
\hline \multicolumn{13}{|l|}{ Outdoor - Floating raft } \\
\hline Engel et al. (2005) & Norwegian Fjord & Spring & $\sqrt{ }$ & Pico/Cyano & $\Leftrightarrow$ & - & & $\Leftrightarrow$ & $\Leftrightarrow$ & $\Leftrightarrow$ & - & Decrease of coccolithophore calcification \\
\hline Kim et al. (2006) & Korean coast & Fall & & Micro/Diat & 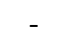 & $\Leftrightarrow$ & & - & - & - & - & \\
\hline Engel et al. (2008) & Norwegian Fjord & Spring & $\sqrt{ }$ & Pico & $\Leftrightarrow$ & $\Leftrightarrow$ & - & $\sqrt{ }$ & $\hat{\imath}$ & - & - & \\
\hline $\begin{array}{l}\text { Paulino et al. (2008) } \\
\text { Schulz et al. (2008) }\end{array}$ & Norwegian Fjord & Spring & $\sqrt{ }$ & - & & $\Leftrightarrow$ & $\Leftrightarrow$ & $\Leftrightarrow$ & $\hat{ن}$ & $\sqrt{3}$ & - & \\
\hline $\begin{array}{l}\text { Hopkins et al. (2010) } \\
\text { Meakin and Wyman (2011) } \\
\text { Newbold et al. (2012) }\end{array}$ & Norwegian Fjord & Spring & $\sqrt{ }$ & Micro & & - & - & 仓 & 仓 & 仓 & - & Increase in large pico-eukaryotes \\
\hline $\begin{array}{l}\text { Kim et al. (2010) } \\
\text { Kim et al. (2011) } \\
\text { Kim et al. (2013) }\end{array}$ & Korean coast & Fall & $\sqrt{ }$ & Diat/Dino & $\Leftrightarrow$ & 仓 & $\Leftrightarrow$ & 仓 & $\Leftrightarrow$ & - & - & Shift from weakly to heavily silified diatoms \\
\hline Calbet et al. (2014) & Norwegian Fjord & Spring & $\sqrt{ }$ & Nano & $\Leftrightarrow$ & $\hat{v}$ & $\sqrt{ }$ & $\hat{\imath}$ & 仓े & - & - & \\
\hline
\end{tabular}

\section{Outdoor - Free floating}


Schulz et al. (2013)

Brussaard et al. (2013)

Czerny et al. (2013)

Paul et al. (2015a)

Bach et al. (2016)

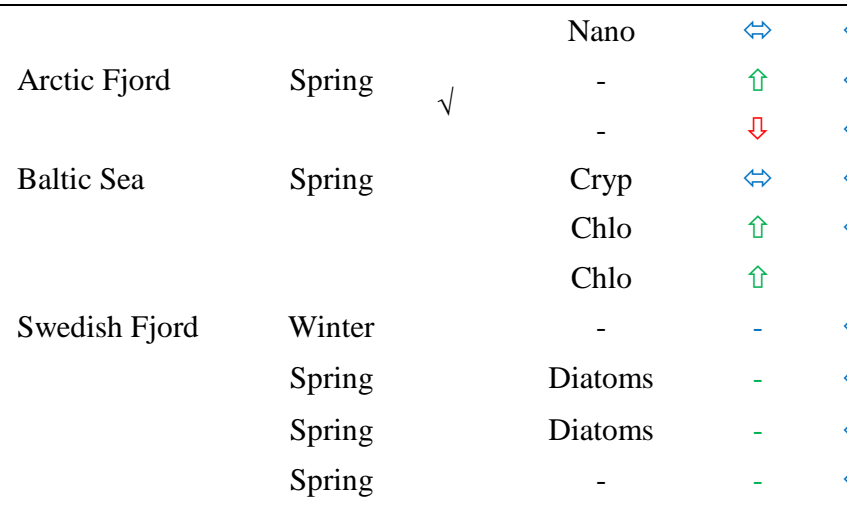

$\begin{array}{ll}\Leftrightarrow & \Leftrightarrow \\ \Leftrightarrow & \uparrow \\ \Leftrightarrow & \uparrow \\ \Leftrightarrow & - \\ \Leftrightarrow & - \\ \qquad & - \\ \Leftrightarrow & \Leftrightarrow \\ \Leftrightarrow & \Leftrightarrow \\ \Leftrightarrow & \Leftrightarrow \\ \Leftrightarrow & \Leftrightarrow\end{array}$

$\Leftrightarrow$
$\Leftrightarrow$
$\Leftrightarrow$
$\Leftrightarrow$
$\Leftrightarrow$
\[ \]
$\Leftrightarrow$
$\Leftrightarrow$
$\Leftrightarrow$
$\Leftrightarrow$

\begin{tabular}{|c|c|c|}
\hline$\Leftrightarrow$ & $\Leftrightarrow$ & $\Leftrightarrow$ \\
\hline 仓 & $\Leftrightarrow$ & $\Leftrightarrow$ \\
\hline$\hat{\imath}$ & $\Leftrightarrow$ & $\sqrt{3}$ \\
\hline$\hat{\imath}$ & $\Leftrightarrow$ & $\Leftrightarrow$ \\
\hline 仓े & $\Leftrightarrow$ & $\Leftrightarrow$ \\
\hline 仓े & $\Leftrightarrow$ & $\Leftrightarrow$ \\
\hline$\Leftrightarrow$ & $\Leftrightarrow$ & - \\
\hline$\Leftrightarrow$ & & - \\
\hline$\hat{\imath}$ & & - \\
\hline$\Leftrightarrow$ & & - \\
\hline
\end{tabular}

Phase 1 before nutrient enrichment

Phase 2

Phase 3

Phase 1

Phase 2

Phase 3

First chlorophyll build-up

Second chlorophyll build-up on remineralized nutrients 
1001 Bay of Calvi in summer 2012. Levels of temperature $\left(\mathrm{T}\right.$ in $\left.{ }^{\circ} \mathrm{C}\right)$, salinity $(\mathrm{S})$, partial pressure of $\mathrm{CO}_{2}\left(p \mathrm{CO}_{2}\right.$ in $\mu$ atm), nitrate + nitrite $\left(\mathrm{NO}_{\mathrm{x}}\right.$ in nmol $\left.1002 \mathrm{~L}^{-1}\right)$ and phosphate $\left(\mathrm{PO}_{4}{ }^{3-}\right.$ in $\left.\mathrm{nmol} \mathrm{L}{ }^{-1}\right)$, ammonium $\left(\mathrm{NH}_{4}{ }^{+}\right.$in $\left.\mathrm{nmol} \mathrm{L}{ }^{-1}\right)$ and silicate $\left(\mathrm{Si}\right.$ in $\left.\mu \mathrm{mol} \mathrm{L}^{-1}\right)$ at the end of the acidification period $($ day 0$)$ 1003 and at the end of the experiment (day 20) are reported. $\mathrm{NO}_{3}{ }^{-}$and $\mathrm{PO}_{4}{ }^{3-}$ data from Louis et al. (in press, this issue). $\mathrm{NH}_{4}{ }^{+}$and $\mathrm{Si}$ data are from 1004 Gazeau et al. (in press, this issue). NA: not available.

\begin{tabular}{cccccccc|ccccccc}
\hline & \multicolumn{7}{c|}{ Day 0} & \multicolumn{7}{c}{ Day 20} \\
& $\mathrm{~T}$ & $\mathrm{~S}$ & $p \mathrm{CO}_{2}$ & $\mathrm{NO}_{\mathrm{x}}$ & $\mathrm{PO}_{4}{ }^{3-}$ & $\mathrm{NH}_{4}^{+}$ & $\mathrm{Si}$ & $\mathrm{T}$ & $\mathrm{S}$ & $p \mathrm{CO}_{2}$ & $\mathrm{NO}_{\mathrm{x}}$ & $\mathrm{PO}_{4}{ }^{3-}$ & $\mathrm{NH}_{4}^{+}$ & $\mathrm{Si}$ \\
\hline OUT & 22.2 & 38.0 & 442 & 50 & 35 & 150 & 1.9 & 24.3 & 38.2 & 489 & $\mathrm{NA}$ & $\mathrm{NA}$ & 660 & 1.8 \\
$\mathrm{C} 1$ & 22.1 & 38.0 & 455 & 59 & $\mathrm{NA}$ & 450 & $\mathrm{NA}$ & $\mathrm{NA}$ & $\mathrm{NA}$ & 456 & 77 & 4 & 190 & 1.1 \\
$\mathrm{C} 2$ & 22.1 & 38.0 & 447 & 53 & 25 & 550 & $\mathrm{NA}$ & 24.2 & 38.2 & 472 & 61 & 6 & 230 & 1.4 \\
$\mathrm{C} 3$ & 22.1 & 38.0 & 444 & 69 & 21 & 210 & $\mathrm{NA}$ & 24.2 & 38.1 & 473 & 59 & 7 & 210 & 1.3 \\
P1 & 22.2 & 38.0 & 583 & $\mathrm{NA}$ & $\mathrm{NA}$ & 330 & $\mathrm{NA}$ & 24.3 & 38.2 & 544 & 45 & 6 & 130 & 1.3 \\
P2 & 22.1 & 38.0 & 698 & 37 & 23 & 400 & $\mathrm{NA}$ & 24.3 & 38.2 & 609 & 41 & 4 & 290 & 1.4 \\
P3 & 22.1 & 38.0 & 753 & 36 & 20 & 225 & 1.7 & 24.2 & 38.2 & 655 & 42 & 10 & 100 & 1.3 \\
P4 & 22.1 & 38.0 & 875 & 30 & 19 & 770 & 1.7 & 24.3 & 38.2 & 764 & 75 & 8 & 230 & 1.2 \\
P5 & 22.1 & 38.0 & 1134 & 37 & 31 & 260 & 1.7 & 24.3 & 38.1 & 754 & 76 & 9 & 350 & 1.3 \\
P6 & 22.1 & 38.0 & 1279 & 57 & NA & 130 & 1.7 & 24.2 & 38.2 & 738 & 61 & 8 & 180 & 1.4 \\
\hline
\end{tabular}


1005

1006

100

1008

1009

Table 3. Environmental and experimental conditions in the nine mesocosms and in the external environment (OUT) during the experiment in the Bay of

Villefranche in winter 2013. Levels of temperature $\left(\mathrm{T}\right.$ in $\left.{ }^{\circ} \mathrm{C}\right)$, salinity $(\mathrm{S})$, partial pressure of $\mathrm{CO}_{2}\left(p \mathrm{CO}_{2}\right.$ in $\mu$ atm $)$, nitrate $\left(\mathrm{NO}_{3}{ }^{-}\right.$in nmol $\left.\mathrm{L}^{-1}\right)$, phosphate $\left(\mathrm{PO}_{4}{ }^{3-}\right.$ in $\left.\mathrm{nmol} \mathrm{L}{ }^{-1}\right)$, ammonium $\left(\mathrm{NH}_{4}{ }^{+}\right.$in $\left.\mathrm{nmol} \mathrm{L}{ }^{-1}\right)$ and silicate $\left(\mathrm{Si}\right.$ in $\left.\mu \mathrm{mol} \mathrm{L} \mathrm{L}^{-1}\right)$ at the end of the acidification period (day 0$)$ and at the end of the experiment (day 12) are reported. *No data are available for day 12 therefore levels on day 11 are reported. $\mathrm{NO}_{3}{ }^{-}$and $\mathrm{PO}_{4}{ }^{3-}$ data from Louis et al. (in press, this issue). $\mathrm{NH}_{4}{ }^{+}$and $\mathrm{Si}$ data are from Gazeau et al. (in press, this issue). NA: not available.

\begin{tabular}{cccccccc|ccccccc}
\hline & \multicolumn{7}{c|}{ Day 0} & \multicolumn{7}{c}{ Day 12 } \\
& $\mathrm{T}$ & $\mathrm{S}$ & $p \mathrm{CO}_{2}$ & $\mathrm{NO}_{3}{ }^{-}$ & $\mathrm{PO}_{4}{ }^{3-}$ & $\mathrm{NH}_{4}{ }^{+}$ & $\mathrm{Si}$ & $\mathrm{T}$ & $\mathrm{S}$ & $p \mathrm{CO}_{2}$ & $\mathrm{NO}_{3}{ }^{-}$ & $\mathrm{PO}_{4}{ }^{3-}$ & $\mathrm{NH}_{4}{ }^{+}$ & $\mathrm{Si}$ \\
\hline OUT & 13.2 & 38.1 & 354 & 1166 & 10 & 62 & 1.3 & 13.2 & 38.2 & 391 & 1307 & 12 & 40 & 1.2 \\
$\mathrm{C} 1$ & 13.2 & 38.1 & 378 & 167 & 10 & 79 & $\mathrm{NA}$ & 13.2 & 38.2 & 388 & 394 & 9 & 49 & 1.0 \\
$\mathrm{C} 2$ & 13.2 & 38.1 & 347 & 118 & 12 & 57 & 1.1 & 13.2 & 38.2 & 354 & 194 & 11 & 31 & 1.1 \\
$\mathrm{C} 3$ & 13.2 & 38.1 & 350 & 110 & 9 & 81 & 1.2 & $\mathrm{NA}$ & $\mathrm{NA}$ & 376 & 127 & 10 & 26 & 1.2 \\
$\mathrm{P} 1$ & 13.2 & 38.1 & 494 & 135 & 10 & 73 & $\mathrm{NA}$ & 13.2 & 38.2 & 429 & 491 & 10 & 68 & 1.1 \\
$\mathrm{P} 2$ & 13.2 & 38.1 & 622 & 133 & 9 & 64 & 1.2 & 13.2 & 38.2 & $413 *$ & $\mathrm{NA}$ & 10 & $\mathrm{NA}$ & $\mathrm{NA}$ \\
$\mathrm{P} 3$ & 13.2 & 38.1 & 691 & $\mathrm{NA}$ & 9 & 64 & 1.2 & $\mathrm{NA}$ & $\mathrm{NA}$ & 451 & 236 & $\mathrm{NA}$ & 26 & 1.2 \\
$\mathrm{P} 4$ & 13.2 & 38.1 & 744 & 72 & 12 & 80 & $\mathrm{NA}$ & 13.2 & 38.2 & 436 & 491 & 9 & 36 & 0.9 \\
$\mathrm{P} 5$ & 13.2 & 38.1 & 932 & 134 & 15 & 60 & 1.2 & 13.2 & 38.2 & 497 & 226 & 10 & 30 & 1.1 \\
P6 & 13.2 & 38.1 & 1250 & 156 & 8 & 60 & 1.1 & $\mathrm{NA}$ & $\mathrm{NA}$ & $579 *$ & $\mathrm{NA}$ & $\mathrm{NA}$ & $\mathrm{NA}$ & $\mathrm{NA}$ \\
\hline
\end{tabular}


1010 Table 4. Stepwise multiple regression analysis between environmental/experimental variables (T: temperature, $\mathrm{S}:$ salinity, $p \mathrm{CO}_{2}:$ partial pressure of $\mathrm{CO}_{2}$,

$1011 \mathrm{NO}_{3}{ }^{-}$: nitrate concentrations, $\mathrm{PO}_{4}{ }^{3-}$ : phosphate concentrations, $\mathrm{NH}_{4}{ }^{+}$: ammonium concentrations, Si: silicate concentrations (only for diatoms), I: daily

1012 integrated photon doses and w: daily averaged wind speeds) and total chlorophyll $a$ (chl $a$ ) concentrations or chlorophyll $a$-equivalent concentrations of

1013 eight taxonomic groups of phytoplankton determined from high performance liquid chromatography (HPLC) measurements using modified CHEMTAX

1014 or Synechococcus, Prochlorococcus, pico-eukaryotes and nano-eukaryotes abundances as measured by flow cytometry, during the experiment in the Bay

1015 of Calvi in summer 2012 and in the Bay of Villefranche in winter 2013. Note that Prochlorococcus and nano-eukaryotes abundances are not available for

1016 the Bay of Calvi and that PON fluxes are not available for the Bay of Villefranche (denoted as NA). Bold text denotes significant correlations $(p<0.01)$

1017 between the considered variable and $p \mathrm{CO}_{2}$ and the sign (+ or -) refers to the sign of the relationship between the considered variable and the

1018 environmental/experimental parameters considered. NS: not significant.

\begin{tabular}{|c|c|c|c|c|c|c|c|c|c|c|c|c|c|c|c|}
\hline Bay of Calvi & $\mathrm{F}$ & Adj. $\mathrm{r}^{2}$ & $\mathrm{df}$ & Overall $p$ & Variable & Sign & $p$ & Bay of Villefranche & $\mathrm{F}$ & Adj. $\mathrm{r}^{2}$ & $\mathrm{df}$ & Overall $p$ & Variable & Sign & $p$ \\
\hline Particulate matter & & & & & & & & Particulate matter & & & & & & & \\
\hline POC & NS & & & & & & & POC & 34.5 & 0.57 & 97 & $<0.001$ & $\begin{array}{l}\mathrm{NO}_{3}{ }^{-} \\
\mathrm{S}\end{array}$ & - & $\begin{array}{l}<0.001 \\
<0.001\end{array}$ \\
\hline PON & 7.0 & 0.06 & 177 & & $\begin{array}{l}\text { I } \\
\text { S }\end{array}$ & & $\begin{array}{c}<0.001 \\
0.003\end{array}$ & PON & 17.3 & 0.32 & 101 & $<0.001$ & $\mathrm{NO}_{3}^{-}$ & - & $<0.001$ \\
\hline POC:PON & 5.2 & 0.09 & 174 & $<0.001$ & $\mathrm{~T}$ & + & $<0.001$ & POC:PON & 9.5 & 0.14 & 99 & $<0.001$ & $\mathrm{NH}_{4}^{+}$ & + & 0.006 \\
\hline Pigments & & & & & & & & Pigments & & & & & & & \\
\hline
\end{tabular}




\begin{tabular}{|c|c|c|c|c|c|c|c|c|c|c|c|c|c|c|}
\hline Total chl $a$ & 27.2 & 0.45 & 156 & $<0.001$ & $\begin{array}{l}\mathrm{S} \\
\mathrm{NH}_{4}^{+}\end{array}$ & $\begin{array}{l}+ \\
+\end{array}$ & $\begin{array}{c}<0.001 \\
0.006\end{array}$ & Total chl $a$ & 22.5 & 0.51 & 100 & $<0.001$ & $\begin{array}{l}\mathrm{I} \\
\mathrm{S} \\
\mathrm{NO}_{3}^{-}\end{array}$ & $\begin{array}{ll}- & <0.001 \\
- & <0.001 \\
- & <0.001\end{array}$ \\
\hline Prasinophyceae & 13.8 & 0.24 & 157 & $<0.001$ & $\begin{array}{l}\mathrm{NO}_{3}^{-} \\
\mathrm{S} \\
\mathrm{I}\end{array}$ & $\begin{array}{l}+ \\
+ \\
+\end{array}$ & $\begin{array}{l}<0.001 \\
<0.001 \\
<0.001\end{array}$ & Prasinophyceae & 18.7 & 0.50 & 99 & $<0.001$ & $\begin{array}{l}\mathrm{T} \\
\mathrm{NO}_{3}^{-} \\
\mathrm{NH}_{4}{ }^{+}\end{array}$ & $\begin{array}{ll}+ & <0.001 \\
+ & <0.001 \\
+ & <0.001\end{array}$ \\
\hline Dinophyceae & 19.5 & 0.36 & 156 & $<0.001$ & $\begin{array}{l}p \mathrm{CO}_{2} \\
\mathrm{I} \\
\mathrm{S} \\
\mathrm{NO}_{3}{ }^{-}\end{array}$ & $\begin{array}{l}+ \\
+ \\
+ \\
-\end{array}$ & $\begin{array}{c}<0.001 \\
<0.001 \\
<0.001 \\
0.001\end{array}$ & Dinophyceae & 14.5 & 0.39 & 100 & $<0.001$ & $\begin{array}{l}\mathrm{S} \\
\mathrm{w}\end{array}$ & $\begin{array}{ll}- & <0.001 \\
- & <0.001\end{array}$ \\
\hline Cryptophyceae & 32.3 & 0.49 & 156 & $<0.001$ & $\begin{array}{l}\mathrm{NO}_{3}^{-} \\
\mathrm{T} \\
\mathrm{I}\end{array}$ & $\begin{array}{l}+ \\
- \\
+\end{array}$ & $\begin{array}{c}<0.001 \\
0.001 \\
0.01\end{array}$ & Cryptophyceae & 58.5 & 0.77 & 99 & $<0.001$ & $\begin{array}{l}\mathrm{S} \\
\mathrm{NO}_{3}^{-} \\
\mathrm{T}\end{array}$ & $\begin{array}{ll}- & <0.001 \\
- & <0.001 \\
- & <0.001\end{array}$ \\
\hline Haptophyceae & 11.4 & 0.28 & 155 & $<0.001$ & $\begin{array}{l}p \mathrm{CO}_{2} \\
\mathrm{I} \\
\mathrm{NO}_{3}^{-}\end{array}$ & $\begin{array}{l}+ \\
+ \\
+\end{array}$ & $\begin{array}{c}<0.001 \\
<0.001 \\
0.002\end{array}$ & Haptophyceae & 20.3 & 0.48 & 100 & $<0.001$ & $\begin{array}{l}\mathrm{T} \\
\mathrm{NO}_{3}^{-} \\
p \mathrm{CO}_{2}\end{array}$ & $\begin{array}{ll}- & <0.001 \\
- & <0.001 \\
- & <0.001\end{array}$ \\
\hline Pelagophyceae & 19.4 & 0.48 & 153 & $<0.001$ & $\begin{array}{l}\mathrm{S} \\
\mathrm{I} \\
\mathrm{T} \\
\mathrm{PO}_{4}{ }^{3-}\end{array}$ & $\begin{array}{l}+ \\
+\end{array}$ & $\begin{array}{c}<0.001 \\
<0.001 \\
0.001 \\
0.005\end{array}$ & Pelagophyceae & 10.6 & 0.27 & 101 & $<0.001$ & $\mathrm{NO}_{3}^{-}$ & $<0.001$ \\
\hline Chlorophyceae & 104 & 0.66 & 158 & $<0.001$ & $\begin{array}{l}\mathrm{S} \\
\mathrm{T}\end{array}$ & $\begin{array}{l}+ \\
+\end{array}$ & $\begin{array}{c}<0.001 \\
0.002\end{array}$ & Chlorophyceae & 12.2 & 0.39 & 99 & $<0.001$ & $\begin{array}{l}\mathrm{NO}_{3}{ }^{-} \\
\mathrm{S} \\
\mathrm{T} \\
\mathrm{I}\end{array}$ & $\begin{array}{ll}+ & 0.001 \\
- & 0.004 \\
+ & 0.004 \\
- & 0.005\end{array}$ \\
\hline
\end{tabular}




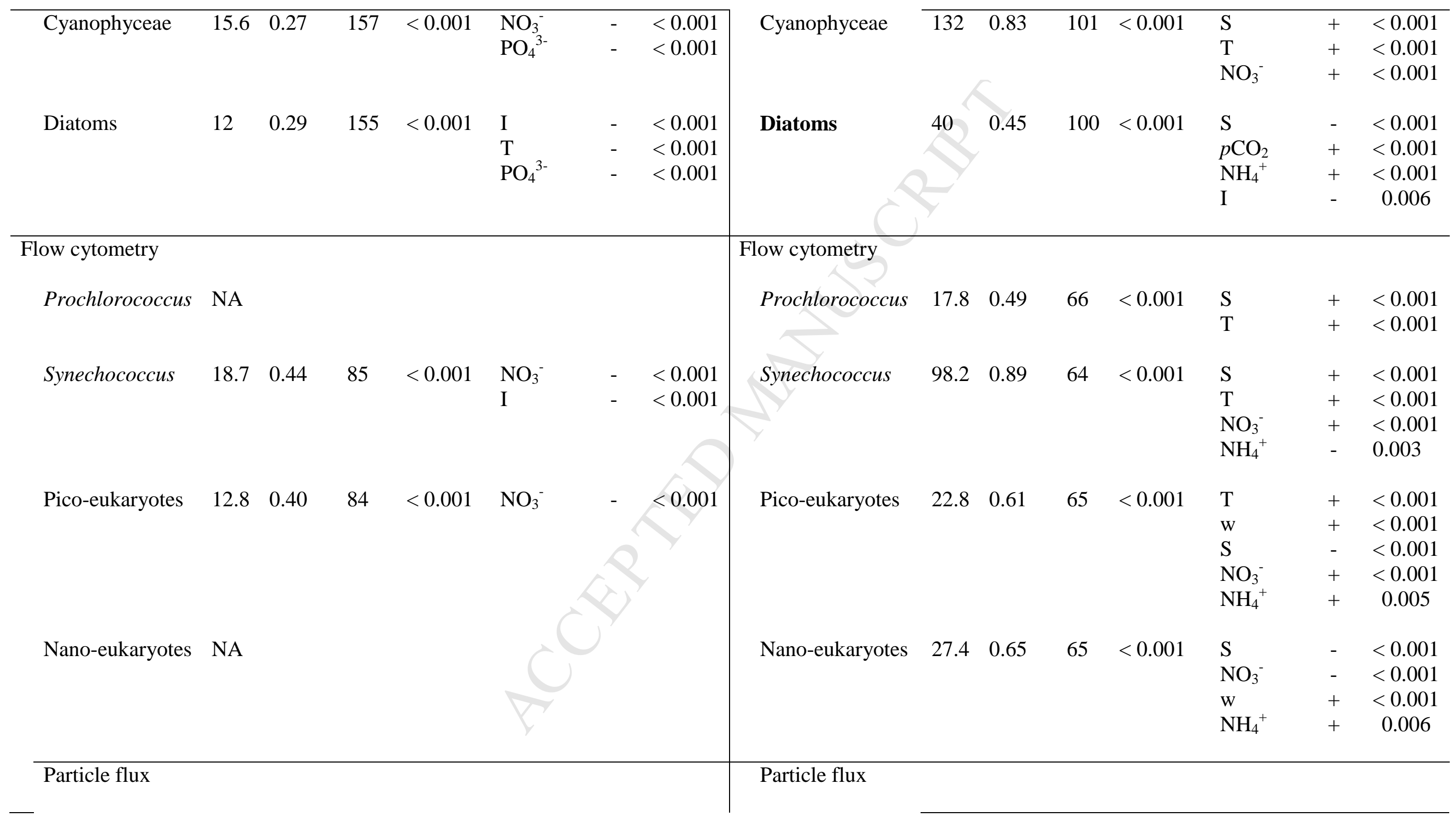




\begin{tabular}{lccccccc|cc} 
& 33.7 & 0.63 & 74 & $<0.001$ & $\mathrm{~T}$ & - & $<0.001$ & POC & NS \\
PON & 34.6 & 0.63 & 74 & $<0.001$ & $\mathrm{~T}$ & - & $<0.001$ & PON & NA \\
& & & & & $\mathrm{NO}_{3}^{-}$ & + & 0.009 & & \\
POC:PON & 22.9 & 0.46 & 75 & $<0.001$ & $\mathrm{~S}$ & + & $<0.001$ & POC:PON & NA
\end{tabular}


Bay of Calvi
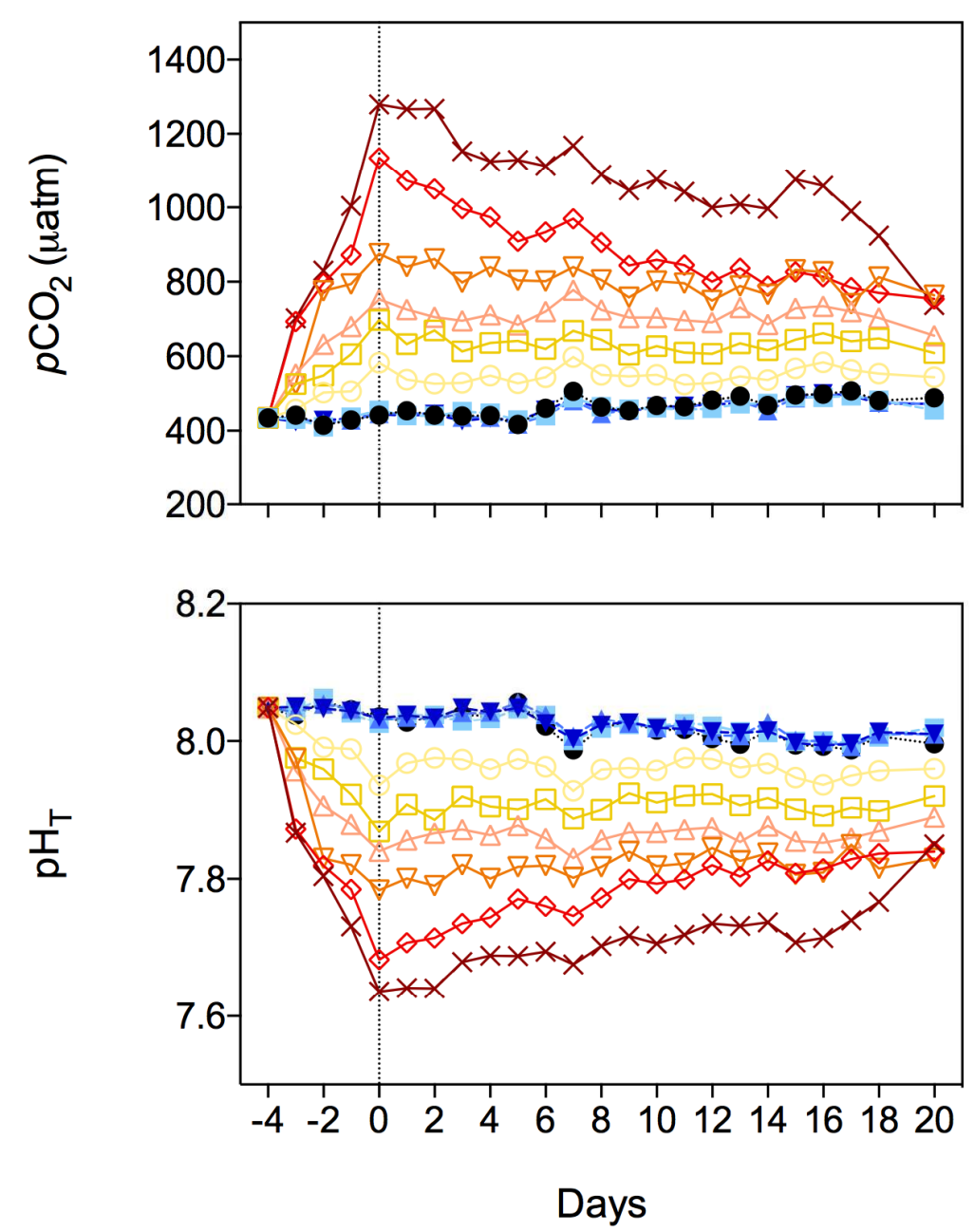

Bay of Villefranche

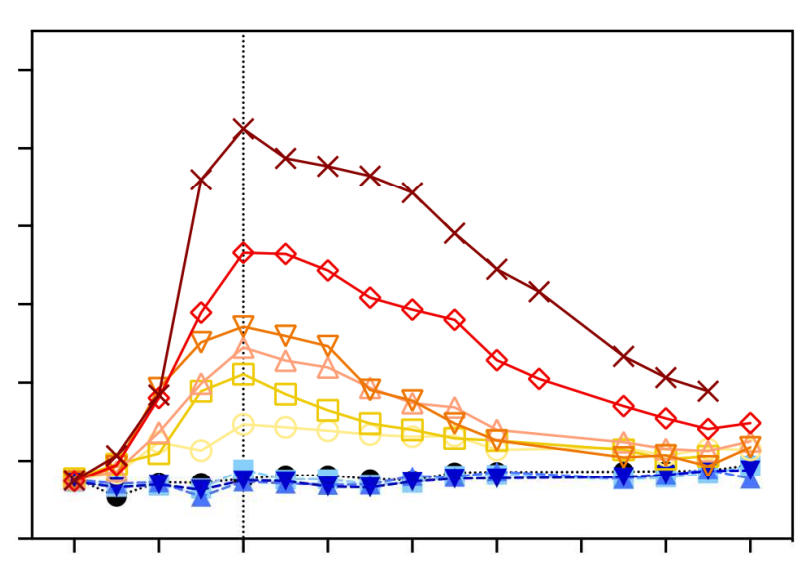

-... OUT

-- C1

-A2

-7-- C3

P1

- P2

$\triangle \mathrm{P3}$

$\nabla$ P4

$\diamond \mathrm{P} 5$

$\times \mathrm{P} 6$

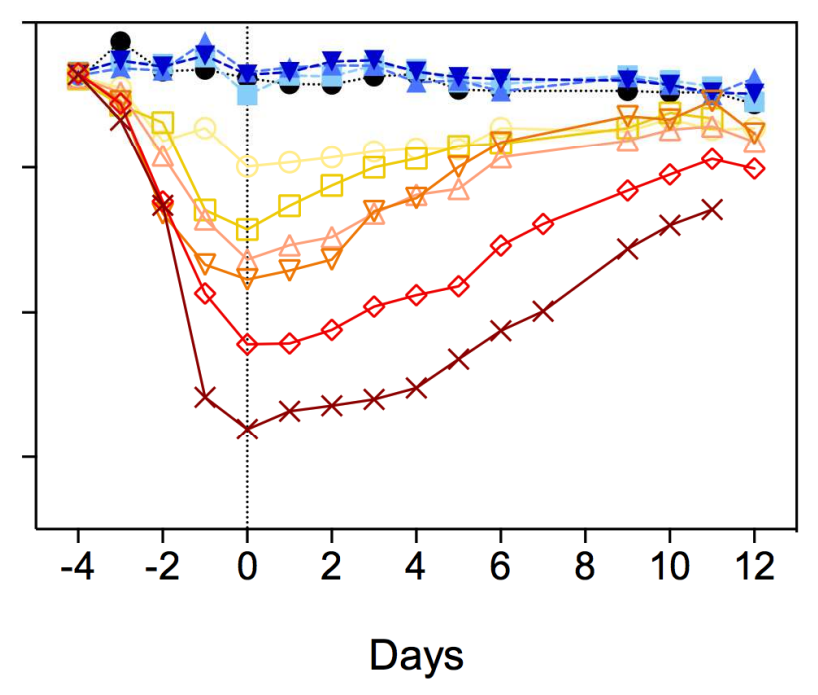

1019

Fig. 1 
Bay of Calvi
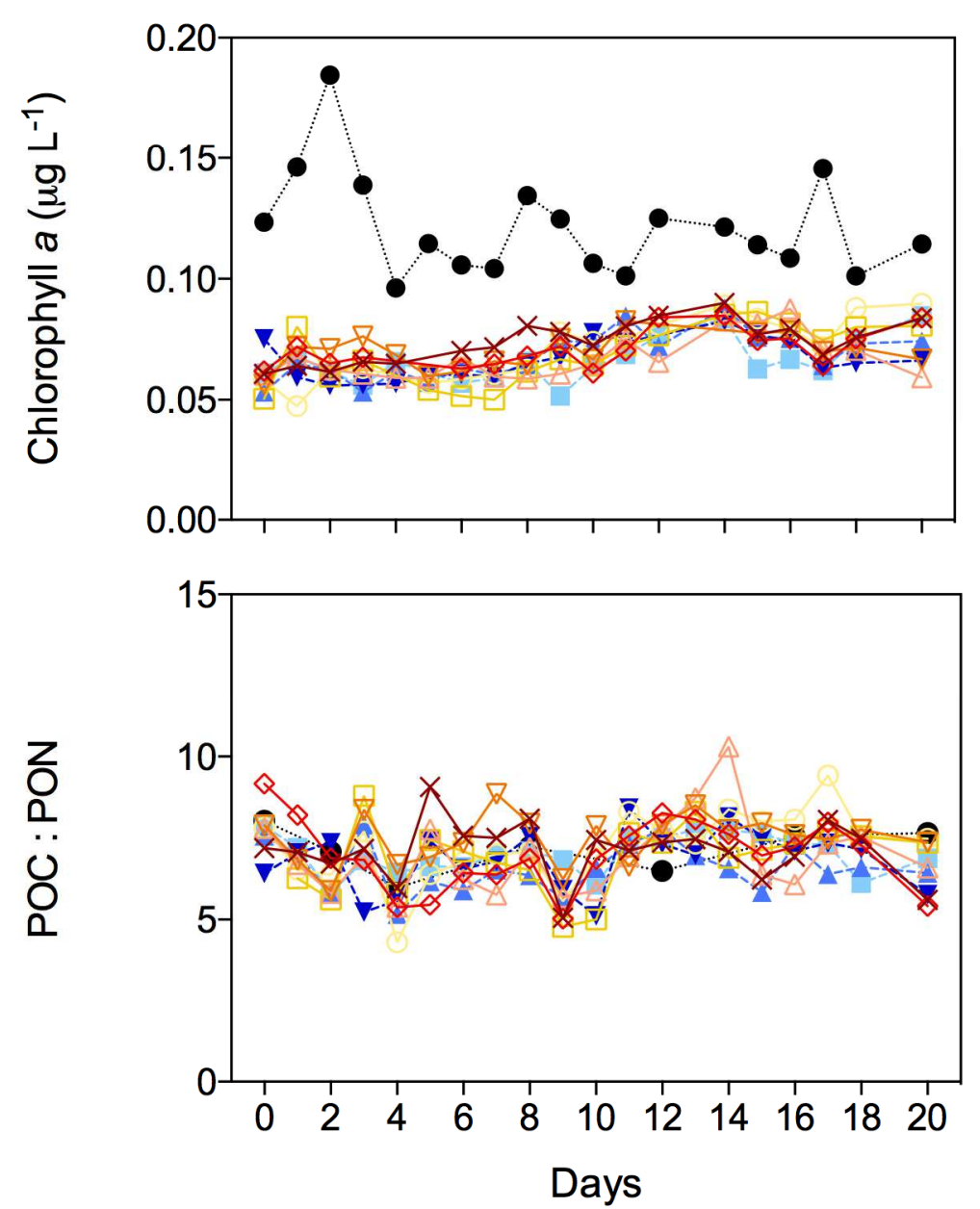

Bay of Villefranche

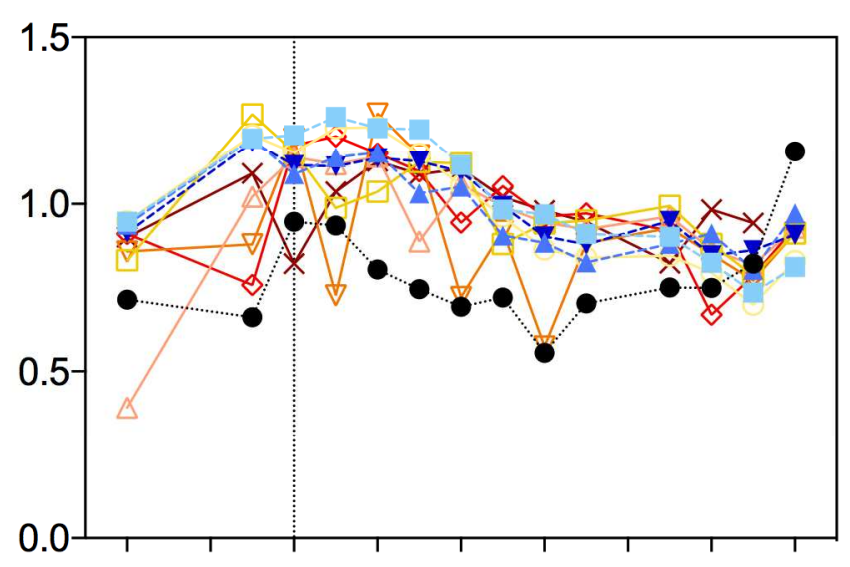

- OUT

C1

$-\mathrm{A}-\mathrm{C2}$

-7. C3

- P1

$\square \mathrm{P} 2$

$\triangle \mathrm{P} 3$

$\rightarrow$ P4

$\rightarrow$ P5

$*$ P6

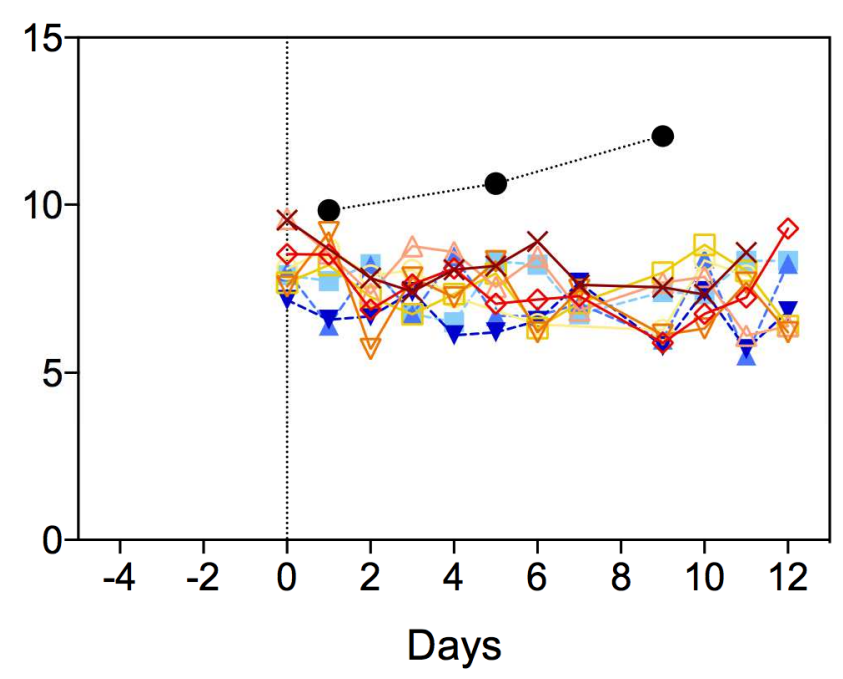




\section{Bay of Calvi}

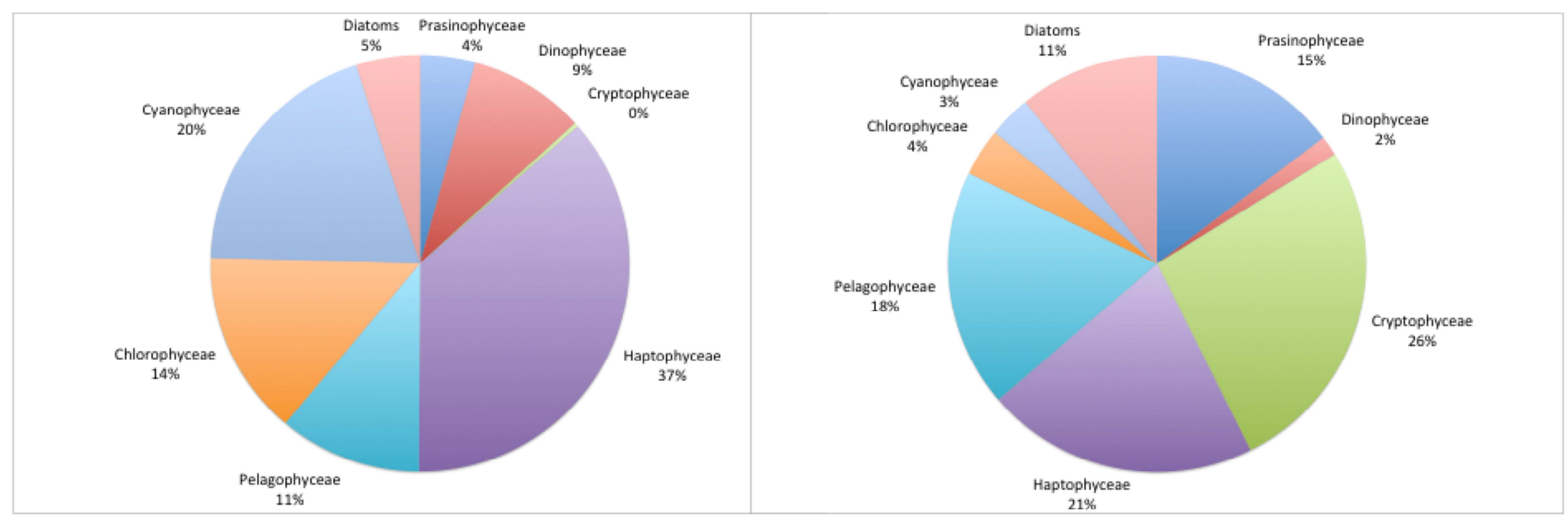




\section{Bay of Calvi}
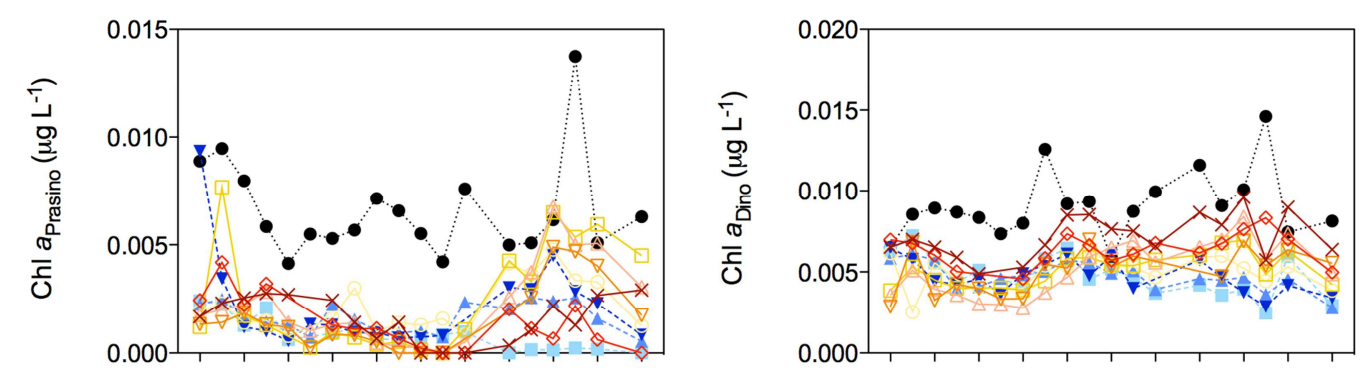

-- OUT

푼- 1

-4 C2

--v- C3
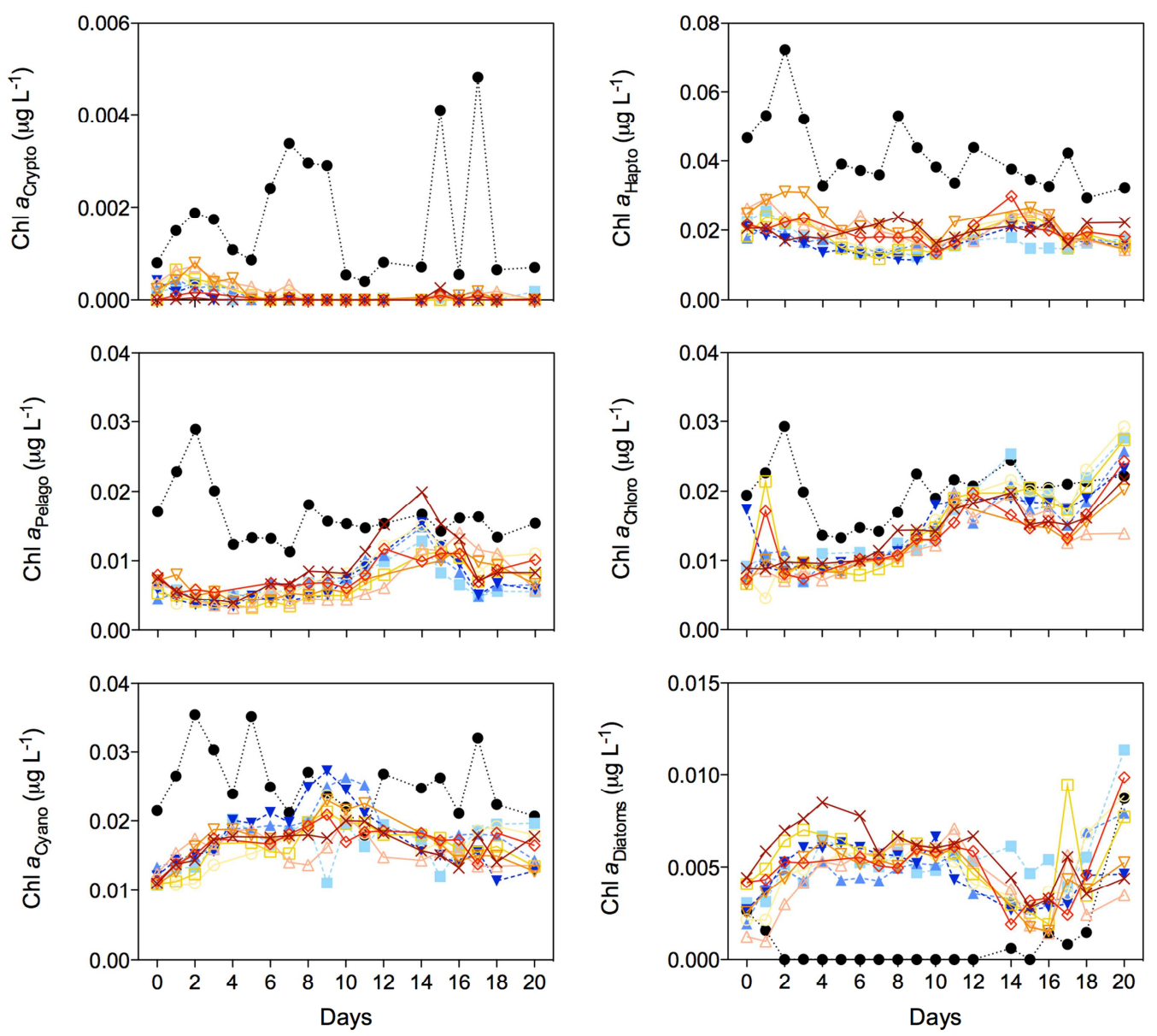

1025

1026 Fig. 4 


\section{Bay of Calvi}

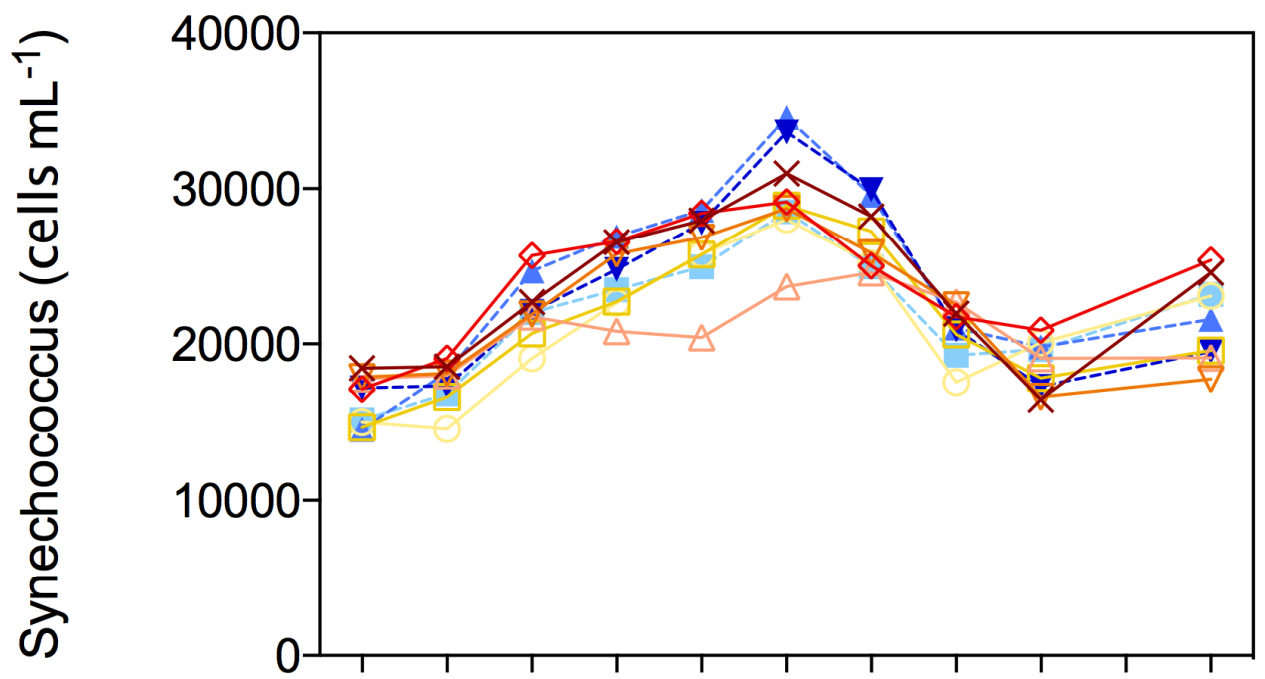

C1

$--\mathrm{C}^{--} \mathrm{C}$

$-\nabla-$ C3

P1

P2

$\triangle \mathrm{P3}$

$\nabla \mathrm{P} 4$

$\diamond$ P5

$* \mathrm{P} 6$

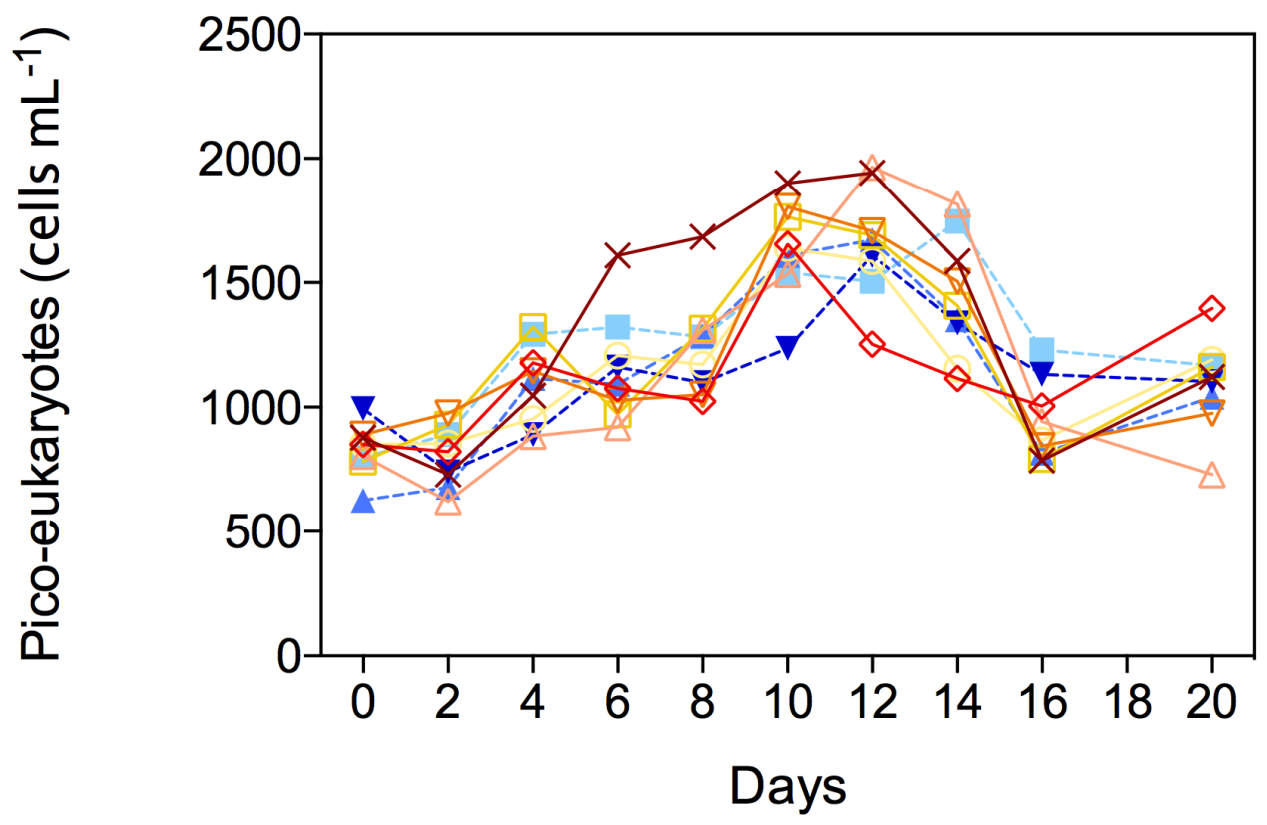

1027

1028 Fig. 5 
1029

\section{Bay of Villefranche}
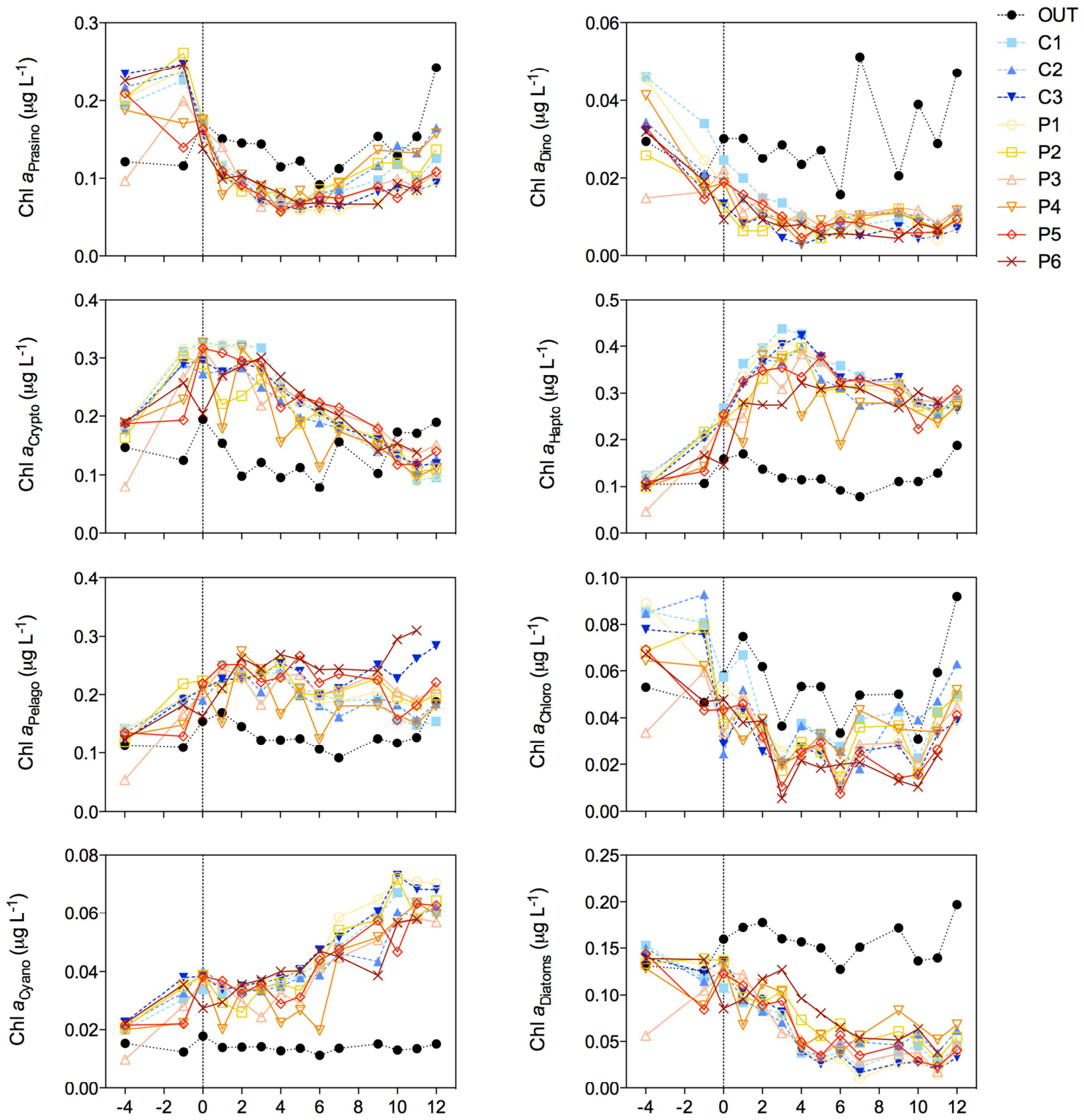

1030

1031 Fig. 6 


\section{Bay of Villefranche}
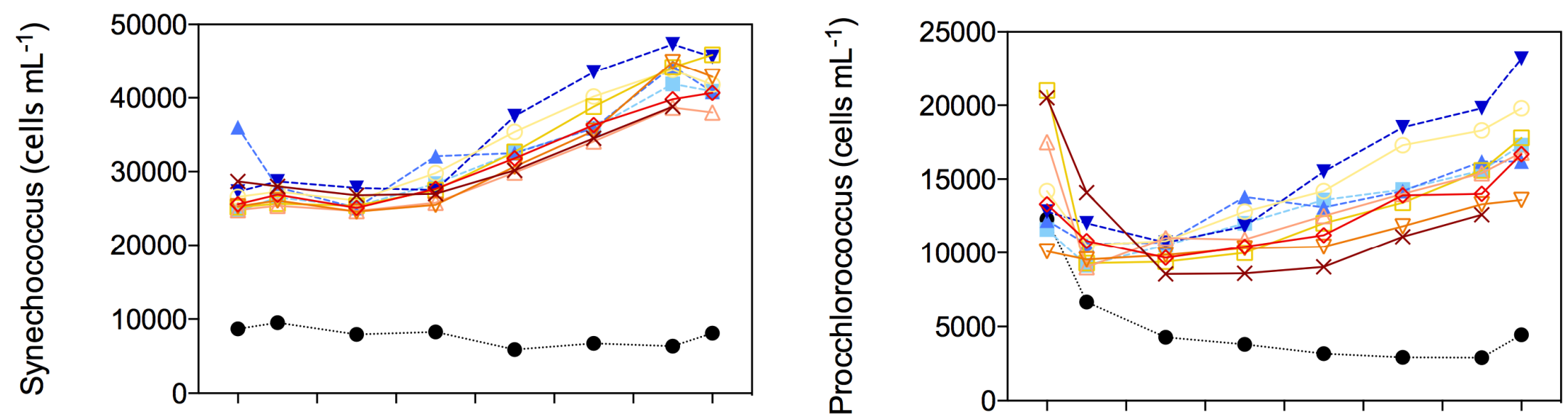

-.. OUT

- C1

-- C2

-7-. C3 $\mathrm{P} 1$

$\square \quad \mathrm{P} 2$

$\triangle$ P3

$\nabla$ P4

$\diamond \mathrm{P} 5$
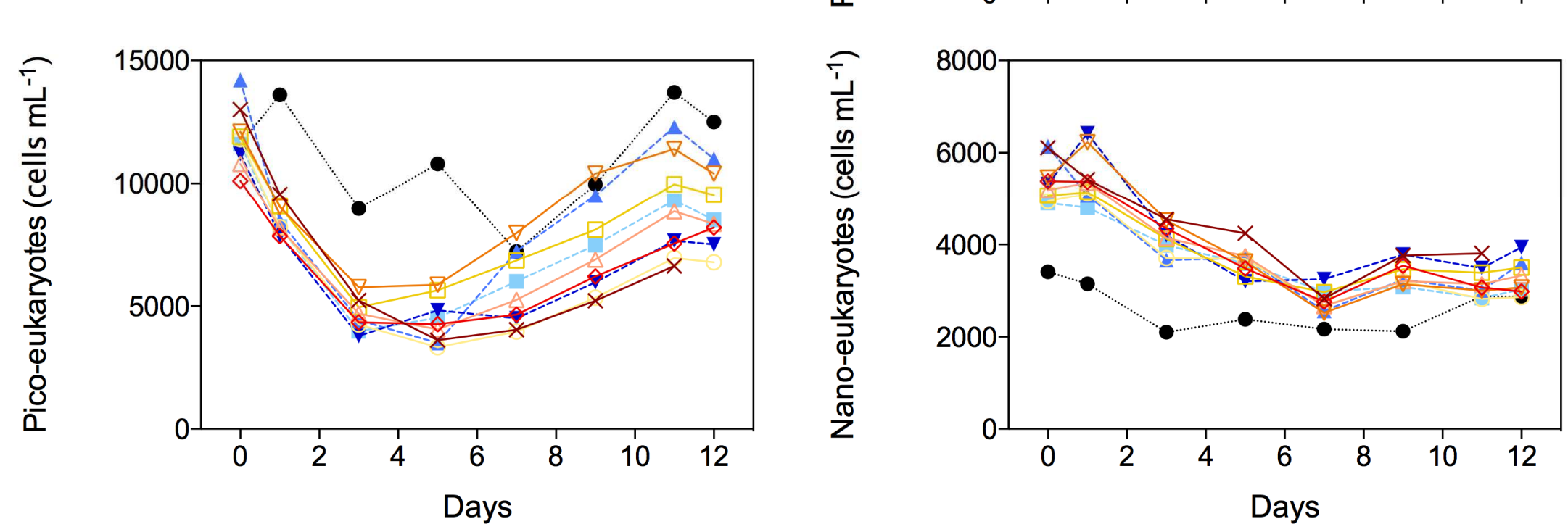

Fig. 7 


\section{Bay of Calvi}
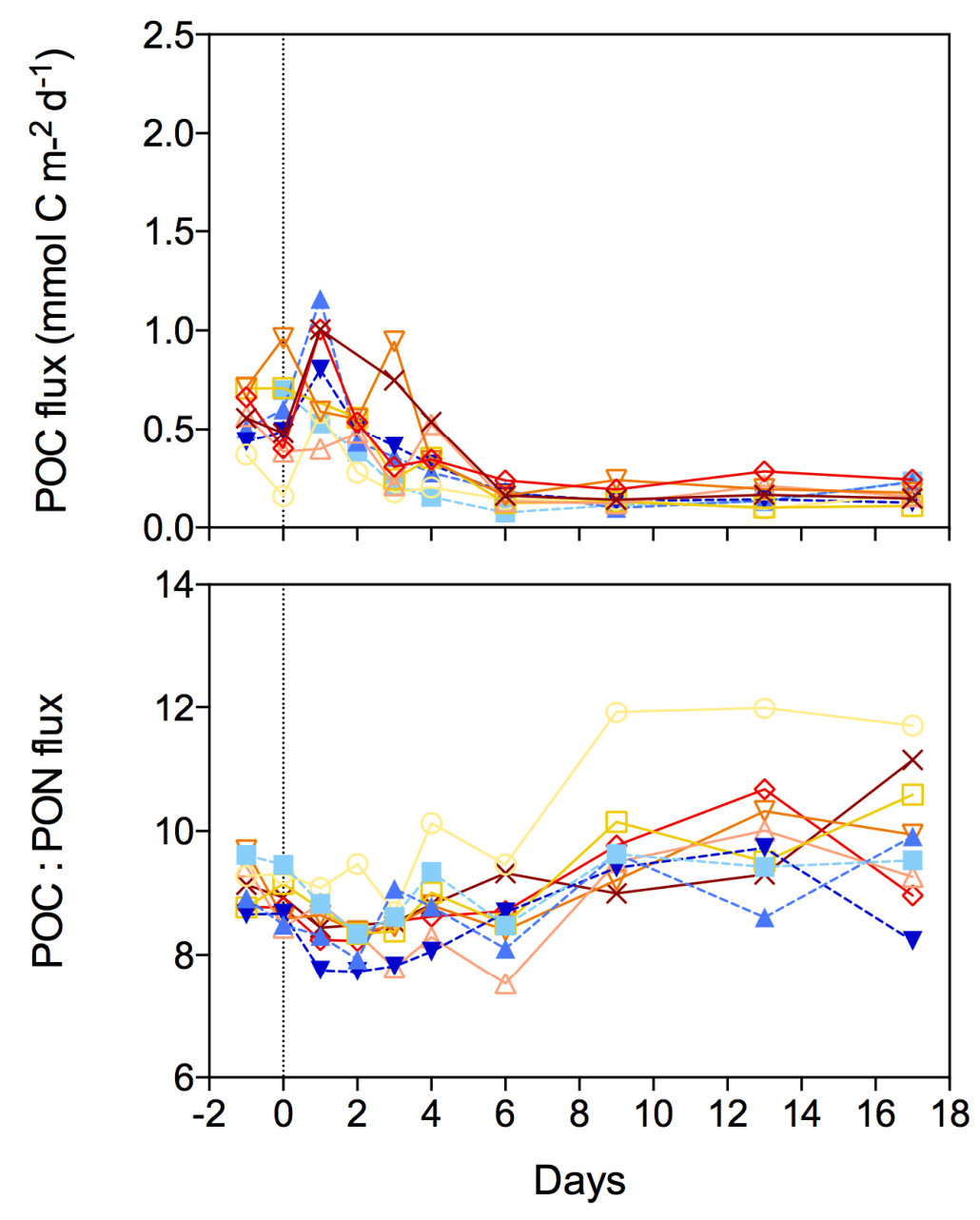

Bay of Villefranche

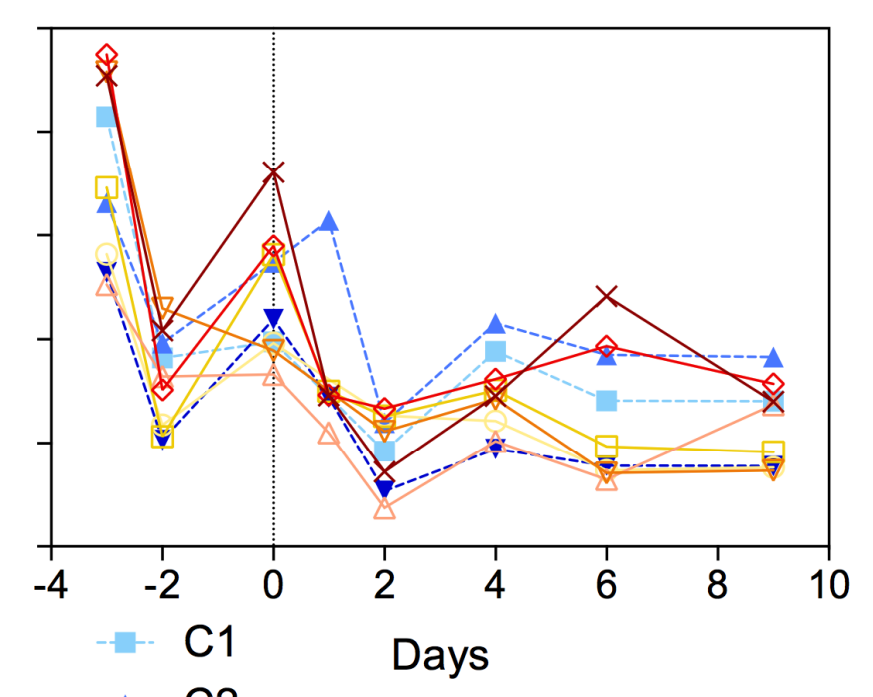

-- C2

-7-. C3

- P1

$\square \quad \mathrm{P} 2$

$\triangle \mathrm{P3}$

$\nabla$ P4

$\diamond \mathrm{P5}$

$\leftarrow$ P6 